\title{
Plant Growth Promoting Rhizobacterial Biofertilizers for Sustainable Crop Production: The Past, Present, and Future
}

\author{
Becky N. Aloo ${ }^{1,2,}{ }^{*}$, Billy A. Makumba ${ }^{3}$ and Ernest R. Mbega ${ }^{1}$ \\ 1 Nelson Mandela African Institution of Science and Technology, Department of Sustainable Agriculture \\ and Biodiversity Conservation, P. O. Box 447, Arusha, Tanzania \\ 2 University of Eldoret, Department of Biological Sciences, P. O. Box 1125-30100, Eldoret, Kenya \\ 2 Moi University, Department of Biological Sciences, P.O. Box 3900-30100, Eldoret, Kenya

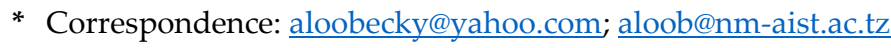

\begin{abstract}
The world's population is increasing and so are agricultural activities to match the growing demand for food. Conventional agricultural practices generally employ artificial fertilizers to increase crop yields, but these have multiple environmental and human health effects. For decades, environmentalists and sustainability researchers have focused on alternative crop fertilization mechanisms to address these challenges, and biofertilizers have constantly been researched, recommended, and even successfully-adopted for several crops. Biofertilizers are microbial formulations made of indigenous plant growth-promoting rhizobacteria (PGPR) which can naturally improve plant growth either directly or indirectly, through the production of phytohormones, solubilization of soil nutrients, and production of iron-binding metabolites; siderophores. Biofertilizers, therefore, hold immense potential as tools for sustainable crop production especially in the wake of climate change and global warming. Despite the mounting interest in this technology, their full potential has not yet been realized. This review updates our understanding of the PGPR biofertilizers and sustainable crop production. It evaluates the history of these microbial products, assesses their present state of utilization, and also critically propounds on their future prospects for sustainable crop production. Such information is desirable to fully evaluate their potential and can ultimately pave the way for their increased adoption for crop production.
\end{abstract}

Keywords: biofertilizers; sustainable agriculture; plant growth-promoting rhizobacteria; microbial formulations

\section{Introduction}

It is approximated that by the year 2050, about 10 billion people will inhabit the earth and a lot of pressure will be mounted on the existing food resources [1]. The intensification of agricultural activities has greatly increased crop productivity all over the globe but has also increased our dependence on chemical inputs like fertilizers and pesticides [2-5]. The use of chemical fertilizers is a common practice around the globe [1] and is almost indispensable [6,7]. However, these chemicals have several negative effects on the environment as outlined by several workers [7-9]. Ironically, the long-term effects of chemical fertilizers also include the overall deterioration of soil quality and productivity [1] and soil acidification which ultimately reduces agricultural productivity [10,11].

Reports show that artificial fertilizers are widely associated with greenhouse gas (GHG) emissions [12-14] which greatly disturb environmental stability and affect both agriculture and natural systems [15], and are expected to rise as agricultural systems expand and to meet the rapidly and equally increasing demand for food. Cognizant of this, there is an urgent need for sustainable 
agricultural practices considerable strides have been made to investigate and implement various environmentally-friendly approaches as alternative crop fertilization mechanisms [16].

Biofertilizers are microbial formulations constituted of beneficial microbial strains immobilized or trapped on inert carrier materials that can be employed to enhance plant growth and increase soil fertility $[9,17]$. Research shows that the yield of various crops can be increased by about $25 \%$ and the use of inorganic $\mathrm{N}$ and $\mathrm{P}$ fertilizers be reduced by about $25-50 \%$ and $25 \%$ respectively through the application of biofertilizers $[18,19]$. Although the concept of biofertilizers is widely researched and there exist several practical applications globally, the utilization of this technology has not reached its full potential for several reasons. This chapter updates our understanding of biofertilizers by exploring their history, types, current status, and future prospects. We believe that such information will provide a good starting point for debate, and concerted global efforts to harness these bioresources as biotechnological-based solutions for sustainable crop production systems.

\section{What are biofertilizers?}

The term 'biofertilizer' has earned several different definitions over the past decades (Table 1), reflecting the development of our understanding of them.

Table 1: Common definitions of biofertilizers from different literature

\begin{tabular}{|c|c|}
\hline Literature & Provided definition \\
\hline$[20]$ & $\begin{array}{l}\text { A biologically-active product or microbial inoculant/formulation containing one } \\
\text { or more beneficial microbes, conserving and mobilizing crop nutrients in the soil }\end{array}$ \\
\hline [21] & $\begin{array}{l}\text { A preparation containing one or more species of microorganisms with the ability } \\
\text { to mobilize important plant nutrients from non-usable form to usable forms }\end{array}$ \\
\hline$[22,23]$ & $\begin{array}{l}\text { A formulated product containing one or more microbes enhancing the nutrient } \\
\text { status of soil and promoting plant growth by availing nutrients and increasing } \\
\text { plant access to nutrients }\end{array}$ \\
\hline $9[24]$ & $\begin{array}{l}\text { A unique, eco-friendly, and cost-effective alternative to chemical fertilizers that } \\
\text { improve crop productivity and soil health sustainably }\end{array}$ \\
\hline [25] & $\begin{array}{l}\text { A formulation or preparation containing latent or live microorganisms with } \\
\text { effective and long-term storage, ease of handling, and delivery of the live } \\
\text { microbes from the factory/lab to the field }\end{array}$ \\
\hline [10] & $\begin{array}{l}\text { A microbial inoculant which colonizes the rhizosphere and improves plant } \\
\text { growth by enhancing nutrient accessibility to plants }\end{array}$ \\
\hline [26] & $\begin{array}{l}\text { A natural product containing a large population of specific beneficial } \\
\text { microorganisms for enhancing soil productivity either by fixing atmospheric } \mathrm{N} \text {, } \\
\text { solubilizing } \mathrm{P} \text { or stimulating plant growth through the synthesis of PGP } \\
\text { substances }\end{array}$ \\
\hline [27] & $\begin{array}{l}\text { A mixture of an active ingredient with a formulated product with inactive or } \\
\text { inert substances. }\end{array}$ \\
\hline [28] & $\begin{array}{l}\text { A formulation that contains microorganisms and/or a biological product that can } \\
\text { fix atmospheric nitrogen, enhance the solubility of soil nutrients, and/or have the } \\
\text { potential to enhance the yield of crop plants }\end{array}$ \\
\hline [29] & $\begin{array}{l}\text { A formulation based on beneficial microbes and/or biological product that either } \\
\text { fixes atmospheric nitrogen or enhance the solubility of soil nutrients and have } \\
\text { the potential to increase the yield of crops }\end{array}$ \\
\hline [30] & $\begin{array}{l}\text { A preparation containing beneficial microorganisms that enhance plant growth } \\
\text { or fertilizers that meet a crop's nutritional requirements through microbiological } \\
\text { means }\end{array}$ \\
\hline [31] & $\begin{array}{l}\text { The means of transporting beneficial microbes from the place of manufacture to } \\
\text { the field for plant application }\end{array}$ \\
\hline
\end{tabular}

In this review, we define biofertilizers as active microbial agents that can stimulate plant growth by enhancing nutrient availability in the rhizosphere [21,32-34]. Other terminologies that are synonymous with biofertilizers include bioformulations or microbial inoculants [35], microbial 
cultures, bioinoculants, bacterial inoculants, or bacterial fertilizers [36]. Nevertheless, the major components of biofertilizers are the plant growth-promoting rhizobacteria (PGPR) whose activities in the plant rhizosphere contribute to the overall increment, accessibility, and concentration of plant nutrients [35,37,38], and are almost indispensable in sustainable agricultural practices [21]. Of all the plant-beneficial microorganisms in the rhizosphere, PGPR are the most promising and have widely been investigated $[21,39,40]$. The use of these microbiomes as biofertilizers in agriculture offers an effective and environmentally-friendly solution for achieving food security [39]. Consequently, biofertilizers and PGPR are well recognized as important components of integrated plant-nutrient management for sustainable agriculture [41].

\section{History of plant growth-promoting rhizobacteria as biofertilizers for crop production}

Whereas the use of microbial formulations is generally considered as a modern biotechnological and novel approach in sustainable agriculture. The inoculation of plants with PGPR to improve yields is a century-old practice [42]. The $1^{\text {st }}$ attempts to this practice date back to as early as the late $18^{\text {th }}$ century when a French scientist by the name Jean-Baptiste Boussingault (1801-1887) recognized that plant growth was proportional to $\mathrm{N}$ quantities. This observation was later linked to the reduction of dinitrogen $\left(\mathrm{N}_{2}\right)$ to ammonium $\left(\mathrm{NH}_{3}\right)$ and the $1^{\text {st }}$ commercial biological fertilizer Nitragin ${ }^{\circledR}$ made from laboratory rhizobial cultures $[43,44]$ was the product of these findings. These were the earliest commercial preparations of PGPR and were patented and marketed close to a century ago [44].

The marketing of Rhizobium inoculants continued in the $19^{\text {th }}$ century $[45,46]$, and their commercial production and marketing expanded worldwide thereafter [47,48]. Since then, a lot of biofertilizers have been formulated and commercialized all over the globe. Soon after this, attempts were made to work to also formulate bacterial soil-fertilizing preparations for non-legume crops, and the $1^{\text {st }}$ preparation 'Alinit' was introduced by the German Albert Caron (1853-1933) based on B. ellenbachensis for enhancing the growth of cereals in Germany [49]. More on the history of these early attempts at bacterial inoculants and biofertilizers is comprehensively covered by Kolbe [50].

Due to the reliability of chemical fertilizers and the inconsistent performance of bioformulations, biofertilizers slowed down for some time but research in the following few decades yielded encouraging results in the greenhouse using root-colonizing Gram-negative Pseudomonas spp. [51-53]. By 1958, in the former Soviet Union, large scale field trials were performed using with Azotobacter and Bacillus spp. on more than 35 million hectares of land [54], but the impact of bacterization was relatively unsatisfactory [55].

The commercialization and application of $\mathrm{N}_{2}$-fixing rhizobia for legumes production have especially been exploited for decades [42]. By the year 2000, the global area of legumes treated with commercial biofertilizers stood at more than 40 million hectares annually [56], and about $1 / 2$ of this was used in soybean fields [47]. In Africa however, the use of rhizobial biofertilizers for legumes production is still negligible, mostly due to inadequate research, information, and markets [57]. The commercial production and utilization of rhizobial inoculants have thus been practices for many decades now, partially reducing the need for mineral fertilizers for legume production in many countries [58]. From the beginning of the $20^{\text {th }}$ century, extensive research has been carried out for the development of state of the art rhizobial bioformulations, and advents of newer techniques have provided inputs in this direction [59].

\section{Types of plant growth-promoting rhizobacterial biofertilizers}

\subsection{Nitrogen fixers}

Plants take up $\mathrm{N}$ from the soil in the form of nitrates $\left(\mathrm{NO}^{3-}\right)$ and ammonium ions $\left(\mathrm{NH}^{4+}\right)[60]$ which are often limiting in soil 
Table 2: Examples of nitrogen-fixing rhizobacteria and potential $\mathrm{N}$ biofertilizers

\begin{tabular}{|c|c|c|}
\hline Crop & Rhizobacteria & Reference(s) \\
\hline \multirow{3}{*}{$\begin{array}{l}\text { Potato (Solanum } \\
\text { tuberosum) }\end{array}$} & Azotobacter, Azospirillum & [63] \\
\hline & Serratia sp., Citrobacter sp., Klebsiella sp., & [64] \\
\hline & Azospirillum sp., Pseudomonas sp., Rhizobium sp. & {$[65]$} \\
\hline \multirow[t]{2}{*}{ Soybean (Glycine max) } & Rhizobium japonicum & [66] \\
\hline & Bradyrhizobium, Streptomyces griseoflavus & [67] \\
\hline \multirow[t]{6}{*}{ Sugarcane (Saccharum officinarum L) } & Kosakania sp. KB117 & [68] \\
\hline & Gluconacetobacter diazotrophicus & [69] \\
\hline & G. diazotrophicus & [70] \\
\hline & P. agglomerans & [71] \\
\hline & K. variicola DX120E & {$[72]$} \\
\hline & Not specified & [73] \\
\hline \multirow[t]{10}{*}{ Rice (Oryza sativa) } & Lysinibacillus sphaericus, K. pneumoniae, B. cereus & [74] \\
\hline & P. stutzeri & [75] \\
\hline & Rhizobium sp., Azospirillum sp & [76] \\
\hline & Pantoea agglomerans, Rahnella aquatilis, P. orientalisj & [77] \\
\hline & Not mentioned & [78] \\
\hline & Microbacterium, Bacillus, Klebsiella spp. Paenibacillus & [79] \\
\hline & kribbensi, B. aryabhattai, K. pneumoniae, B. subtilis, $M$. & {$[80,81]$} \\
\hline & trichotecenolyticum & \\
\hline & $\begin{array}{l}\text { Burkholderia, Herbaspirillum, Azospirillum, } R \text {. } \\
\text { leguminosarum }\end{array}$ & \\
\hline & Not specified & [73] \\
\hline \multirow[t]{8}{*}{ Maize (Zea mays) } & $\begin{array}{l}\text { Klebsiella sp., K. pneumoniae, } B . \\
\text { pumilus, Acinetobacter sp. }\end{array}$ & {$[82]$} \\
\hline & B. mojavensis, $P$. aeruginosa, Alcaligenes faecalis, $P$. & [83] \\
\hline & syringiae, B. cereus & [84] \\
\hline & P. protegens & [85] \\
\hline & P. aeruginosa, E. asburiae, Acinetobacter brumalii & [86] \\
\hline & Herbaspirillum species & [87] \\
\hline & Bacillus sp., Enterobacter sp. & [88] \\
\hline & P. pseudoalcaligenes, $P$. aeruginosa & \\
\hline \multirow[t]{2}{*}{ Green gram (Vigna radiate) } & Rhizobium sp. & [89] \\
\hline & Bradyrhizobium, Streptomyces griseoflavus & [67] \\
\hline \multirow[t]{2}{*}{ Groundnut (Arachis hypogaea) } & Enterobacter ludwigii & [90] \\
\hline & Bradyrhiziobium & [91] \\
\hline \multirow[t]{5}{*}{ Wheat (Triticum aestivum L.) } & P.protegens & [84] \\
\hline & Stenotrophomonas maltophilia, Chryseobacterium, & {$[92]$} \\
\hline & $\begin{array}{l}\text { Flavobacterium, P. Mexicana } \\
\text { Achromobacter insolitus, Azospirillum brasisilense }\end{array}$ & {$[93]$} \\
\hline & Azotobacter chroococcum & {$[94]$} \\
\hline & Azospirillum brasilense & [95] \\
\hline \multirow[t]{2}{*}{ Tomato (Solanum lycopersicum L.) } & $\begin{array}{l}P . \text { gessardi, } P . \text { koreensis, } P . \\
\text { brassicacearum, } P . \\
\text { marginalis, Acinetobacter } \\
\text { calcoaceticus and Rahnella aquatica }\end{array}$ & [96] \\
\hline & Not specified & [73] \\
\hline Banana (Musa sp.) & $\begin{array}{l}\text { Klebsiella sp., Bacillus sp., Microbacterium sp., } \\
\text { Enterobacter sp., }\end{array}$ & {$[97]$} \\
\hline
\end{tabular}

Therefore, artificial $\mathrm{N}$ fertilizers are often heavily utilized to enhance $\mathrm{N}$ nutrition in plants. Alarmingly, the global use of synthetic $\mathrm{N}$ is rapidly expanding and the Food and Agriculture Organization (FAO) estimates that their demand exceeds 130 million tons per year which is environmentally unsuitable especially since their production largely depends on the use of fossil fuels [61,62]. 
Biological nitrogen fixation (BNF) is a widely-investigated phenomenon where certain microbes fix $\mathrm{N}$ for plant use using the nitrogenase enzyme complex [98]. For instance, the $\mathrm{N}_{2}$-fixing rhizobia in leguminous plants have been researched for several decades [99]. Several controlled studies involving the inoculation of different crop plants have shown $\mathrm{N}$ fixation and biomass yield in plants inoculated with $\mathrm{N}$-fixers relative to un-inoculated controls. Several instances demonstrating BNF by rhizobacteria with the potential to be used as biofertilizers for different crops are displayed in Table 2. Some of these have successfully been formulated into commercial biofertilizers but the commercially available $\mathrm{N}$ biofertilizers mostly consist of Rhizobium, and a few other bacteria such as Azotobacter, and Azospirillum species and are widely applicable to legume crops [100].

Inoculating crops and agricultural fields with PGPR capable of BNF can help to provide the required $\mathrm{N}$ levels [101]. Evidence shows that rhizobial $\mathrm{N}_{2}$ fixation rates of $1-2 \mathrm{~kg} \mathrm{~N}^{-1} \mathrm{day}^{-1}$ can be obtained in legume fields [33]. Herridge proposed that the replacement of chemical fertilizers with rhizobial inoculants would reduce the annual cost of $\mathrm{N}$ fertilization to about US $\$ 1$ million from US $\$ 30$ million per year. The provided examples illustrate the importance of symbiotic and associative $\mathrm{N}_{2}-$ fixing rhizobacteria. Nevertheless, there is need to perform field trials of new strains for suitability and adaptability before application as inoculants [33].

For decades, several efforts have been made to demonstrate endophytic and associative $\mathrm{N}_{2}$ fixation in non-leguminous crops using free-living diazotrophs like Azotobacter, Azospirillum, Gluconaceotobacter, and Burkholderia [102]. For instance, studies by Hungria et al. [103] and Melchiorre et al. [104] respectively demonstrated that grain yields in Brazil, Argentina, and the United States of America (USA) could reach up to $4 \mathrm{t} \mathrm{ha}^{-1}$ per growing season through BNF by rhizobial inoculants. Similarly, in Australian soils, $\mathrm{N}_{2}$ fixation rates of up to $40 \mathrm{~kg} \mathrm{~N}^{-1}$ year-1 $^{-1}$ are documented [105]. However, the contribution of symbiotically-fixed $\mathrm{N}$ to plants remains largely unestablished and wanting. More research in this area is definitely necessary especially for crops like cereals, vegetables, and tubers, considering they contribute to the bulk of human food.

\subsection{Nutrient solubilizers}

\subsubsection{Phosphate solubilizers}

Phosphorus is the $2^{\text {nd }}$ most essential plant macronutrient [106]. However, plants can only take it up as monobasic $\left(\mathrm{H}_{2} \mathrm{PO}_{4}^{-}\right)$or dibasic $\left(\mathrm{HPO}_{4}^{-2}\right)$ ions yet between 95 and $99 \%$ of soil P occurs in insoluble, immobilized, or precipitated forms that are not plant-available $[60,107]$. Consequently, only a small percentage of the total soil $\mathrm{P}$ is utilizable by crops and is rarely sufficient [108-110]. Many PGPR have attracted the attention of researchers as plant inoculants due to their P solubilization abilities [60,111]. Since P deficiency is inherent in many agricultural soils, such organisms are largely proposed as prospective $\mathrm{P}$ biofertilizers [112]. Literature shows that P-solubilizing bacteria (PSB) secrete various enzymes and metabolites that solubilize $\mathrm{P}$ [113], but the solubilization of $\mathrm{P}$ is largely advanced to occur by acidification [113,114]. For instance, recent studies by Zeng et al. [115] successfully demonstrated that the P solubilizing activities of Pseudomonas frederiksbergensis positively correlated with the production of organic acids.

There are numerous reports concerning the growth stimulation of crops owing to inoculation with PSB, examples of which are provided in Table 3. Similarly, several reviews have also highlighted the importance, potential, and mechanisms of P solubilization by PSB [116-119]. Despite the growing volume of literature, studies regarding their use as biofertilizers are still limited [60].

Table 3: Examples of phosphates solubilizing rhizobacteria and potential P biofertilizers

\begin{tabular}{l|ll} 
Crop & Rhizobacteria & Reference(s) \\
\hline Potato (Solanum tuberosum) & B. megaterium & {$[63]$} \\
& Bacillus spp., Pseudomonas spp., Serratia spp. & {$[123]$} \\
& Serratia sp., Citrobacter sp., Klebsiella sp. & {$[64]$} \\
& Pseudomonas sp., B. subtilis & {$[124]$}
\end{tabular}




\begin{tabular}{|c|c|c|}
\hline Bananas (Musa spp.) & $\begin{array}{l}\text { B. subtilis, Agrobacterium tumefaciens, Streptomyces } \\
\text { sp., B. thuringiensis, B. amyloliquefaciens, } \\
\text { Micrococcus luteus }\end{array}$ & [125] \\
\hline Maize (Zea mays) & $\begin{array}{l}\text { B. mojavensis, P. aeruginosa, Alcaligenes faecalis, P. } \\
\text { syringiae, B. cereus } \\
\text { Lysinibacillus fusiformis } \\
\text { P. fluorescens } \\
\text { Bacillus spp., Klebsiella sp., E. ludwigii, Pantoea spp. } \\
\text { P. aeruginosa, E. asburiae, Acinetobacter brumalii } \\
\text { Klebsiella sp., K. pneumoniae, B. pumilus } \\
\text { Acinetobacter sp. and B. subtilis }\end{array}$ & $\begin{array}{l}{[83]} \\
{[126]} \\
{[127]} \\
{[128]} \\
{[85]} \\
{[82]}\end{array}$ \\
\hline Soybean (Glycine max) & $\begin{array}{l}\text { R. japonicum } \\
\text { E. sakazakii, P. straminae, Acinetobacter calcoaceticus } \\
\text { B. acidiceler, B. megaterium, B. pumilus, } \\
\text { B. safensis, B. simplex, Lysinibacillus } \\
\text { fusiformis, Paenibacillus cineris and } \\
\text { P. graminis } \\
\text { P. plecoglossicida }\end{array}$ & $\begin{array}{l}{[66]} \\
{[129]} \\
{[130]}\end{array}$ \\
\hline Wheat (Triticum aestivum L.) & $\begin{array}{l}\text { P. putida, Azospirillum } \\
\text { Serratia marcescens } \\
\text { Pseudomonas sp., P. mosselii } \\
\text { P. mosselii } \\
\text { Stenotrophomonas maltophilia, Chryseobacterium, } \\
\text { Flavobacterium, P. mexicana } \\
\text { Non-identified strains }\end{array}$ & $\begin{array}{l}{[132]} \\
{[133]} \\
{[112]} \\
{[134]} \\
{[92]} \\
{[135]}\end{array}$ \\
\hline Poplar (Populus spp.) & P. frederiksbergensis & [115] \\
\hline Cowpea (Vigna unguiculata) & Bradyrhizobium japonicum & [136] \\
\hline Sugarcane (Saccharum officinarum L) & $\begin{array}{l}\text { Herbaspirillum spp., Bacillus spp. } \\
\text { Burkholderia mallei, B. cepacia, Proteus vulgaris, } \\
\text { Pasteurella multocida, K. pneumoniae, K. oxytoca, E. } \\
\text { cloacae, C. freundii } \\
\text { G. diazotrophicus } \\
\text { Not identified }\end{array}$ & $\begin{array}{l}{[137]} \\
{[138]} \\
{[139]} \\
{[73]}\end{array}$ \\
\hline Chickpea (Cicer arietinum) & $\begin{array}{l}\text { B. subtilis, B. licheniformis } \\
\text { Bacillus sp., Klebsiella sp., Pseudomonas sp. } \\
\text { P. agglomerans, B. cereus, B. sonorensis }\end{array}$ & $\begin{array}{l}{[140]} \\
{[141]} \\
{[142]}\end{array}$ \\
\hline Mungbean (Vigna radiate) & $\begin{array}{l}\text { P. agglomerans, Burkholderia anthina } \\
\text { B. circulans, Cladosporium herbarum } \\
\text { B. subtilis, B. licheniformis }\end{array}$ & $\begin{array}{l}{[143]} \\
{[111]} \\
{[140]}\end{array}$ \\
\hline Tomato (Solanum lycopersicum L.) & $\begin{array}{l}P . \text { gessardi, P. koreensis, P. brassicacearum, } P . \\
\text { marginalis, Acinetobacter calcoaceticus and Rahnella } \\
\text { aquatica } \\
\text { Not specified }\end{array}$ & [73] \\
\hline Rice (Oryza sativa) & $\begin{array}{l}\text { S. marcescens, Pseudomonas sp. } \\
\text { Rahnella aquatillis, Enterobacter sp., P. } \\
\text { fluorescens and P. putida } \\
\text { P. agglomerans, Rahnella aquatilis and P. orientalis } \\
\text { Not mentioned } \\
\text { Paenibacillus kribbensi, B. aryabhattai, K. } \\
\text { pneumoniae, B. subtilis, Microbacterium } \\
\text { trichotecenolyticum } \\
\text { Not speciied }\end{array}$ & $\begin{array}{l}{[144]} \\
{[145]} \\
{[77]} \\
{[78]} \\
{[79]}\end{array}$ \\
\hline Coffee (Coffea arabica L.) & $\begin{array}{l}\text { Pseudomonas sp., Bacillus sp., } \\
\text { Enterobacter sp. and } \\
\text { Stenotrophomonas sp. }\end{array}$ & [146] \\
\hline
\end{tabular}




\begin{tabular}{l|ll} 
& P. chlorophis, Erwinia rapontici, Bacillus sp., Serratia & [147] \\
& marcescens & \\
\hline Cotton (Gossypium hirsutum) & Azotobacter chroococcum & {$[94]$} \\
& B. megaterium, P. putida, P. fluorescens & {$[148]$} \\
\hline Various leguminous and non- & Azotobacter sp., Mesorhizobium sp., Pseudomonas sp., & {$[149]$} \\
leguminous plants & Bacillus sp., Rhizobium sp. & \\
\hline
\end{tabular}

The economically-mineable $\mathrm{P}$ deposits are limited [120]. The world's main P source; rock phosphate is a non-renewable resource whose mining also contributes largely to global energy consumption, and therefore extremely unsustainable environmentally [33]. There is no doubt that through P solubilization, bacterial biofertilizers can significantly increase crop yields [121], and that the use of PSB as bioinoculants can open up a new horizon for maintaining soil P levels and by large, sustainable crop productivity [122]. However, despite several encouraging field inoculation studies, field results are still generally inconsistent, calling for more research.

\subsubsection{Potassium solubilizers}

Potassium is the $3^{\text {rd }}$ major plant macronutrient $[60,150,151]$, but $>90 \%$ of soil K exists in insoluble complexes and the available quantities are usually insufficient for plant growth [152,153]. Reports show that $\mathrm{K}$ deficiency is a major challenge in crop production worldwide $[60,154]$. Artificial $\mathrm{K}$ fertilizers are often used to supplement $\mathrm{K}$ in agricultural soils, but these are costly and condense profit margins for farmers $[150,155]$. It is therefore essential to find alternative ways of improving $\mathrm{K}$ availability to sustain crop production [156,157].

The ability of PGPR to solubilize K from K-bearing rocks through the secretion of organic acids has widely been investigated [60,152], and K solubilizing bacteria (KSB) have been demonstrated to have prominent roles in improving crop growth and yield [158]. For instance, reports show that these bacteria can significantly improve the germination, nutrient uptake, growth, and yield of crops under both controlled and field conditions [158,159]. In Table 4, we summarize some examples of KSB that have been associated with improved K-uptake in different plants.

Although the solubilization of K-bearing rocks may not entirely fulfill the total plant $\mathrm{K}$ requirements like the commercial fertilizers, studies show that this novel approach may significantly enhance K availability in agricultural soils [174]. Furthermore, literature strongly progresses that the application of KSB to agricultural soils as biofertilizers can greatly cut the use of chemical fertilizers $[175,176]$, and are eco-friendly approaches to crop production [165,173,177]. Indigenous KSB are especially in the limelight and emerging as some of the viable technologies for mitigating K deficiency in agricultural soils [178].

The diversity, solubilizing abilities, and mechanisms of KSB are extensively reviewed by Sattar et al. [174], Ahmad et al. [150], and Sindhu et al. [179]. Despite this burgeoning volume of literature, little is still known about the efficacy of KSB and how they can influence plant growth under different agro-climatic conditions [180].

Table 4: Examples of potassium solubilizing rhizobacteria and potential $\mathrm{K}$ solubilizers

\begin{tabular}{l|ll}
\multicolumn{1}{c}{ Bacteria } & \multicolumn{1}{c}{ Crop } & Reference \\
\hline Potato (Solanum tuberosum) & B. circulans & {$[63]$} \\
& Klebsiella sp., Citrobacter sp., Serratia sp. & {$[64]$} \\
\hline Wheat (Triticum aestivum) & Paenibacillus kribbensis & {$[159]$} \\
& Pseudomonas, Bacillus, Stenotrophomonas, & {$[160]$} \\
& Methylobacterium, Arthrobacter, Pantoea, & \\
& Achromobacter, Acinetobacter, & \\
& Exiguobacterium, Staphylococcus & {$[161]$} \\
& Not identified & \\
\hline
\end{tabular}




\begin{tabular}{|c|c|c|}
\hline Common bean (Phaseolus vulgaris) & $\begin{array}{l}\text { Acinetobacter sp., Bacillus sp., Enterobacter } \\
\text { sp., Micrococcus sp., Pseudomonas sp. }\end{array}$ & [162] \\
\hline Maize (Zea mays) & $\begin{array}{l}\text { B. mojavensis, P. aeruginosa, Alcaligenes } \\
\text { faecalis, P. syringiae, B. cereus } \\
\text { B. licheniformis, B. subtilis } \\
\text { K. oxytoca }\end{array}$ & $\begin{array}{l}{[83]} \\
{[163]} \\
{[164]}\end{array}$ \\
\hline $\begin{array}{l}\text { Sorghum (Sorghum bicolor) and } \\
\text { Chilli (Capsicum sp.) }\end{array}$ & Bacillus, Pseudomonas sp. & [165] \\
\hline Tomato (Solanum lycopersicum L.) & $\begin{array}{l}\text { P. gessardi, P. koreensis, P. brassicacearum, P. } \\
\text { marginalis, Acinetobacter } \\
\text { calcoaceticus and Rahnella aquatica } \\
\text { Not specified }\end{array}$ & $\begin{array}{l}{[96]} \\
{[73]}\end{array}$ \\
\hline Black pepper (Piper nigrum) & $\begin{array}{l}\text { Paenibacillus glucanolyticus } \\
\text { B. megaterium var phosphaticum, B. } \\
\text { mucilaginosus }\end{array}$ & $\begin{array}{l}{[166]} \\
{[167]}\end{array}$ \\
\hline Chickpea (Cicer arietinum) & P. jessenii, Mesorhizobiumciceri & {$[168]$} \\
\hline Fava/faba bean (Vicia faba) & Rhizobium sp. & [169] \\
\hline Apples (Malus domestica) & $\begin{array}{l}\text { B. subtilis, B. licheniformis, B. pumilus, B. } \\
\text { methylotrophicus, B. firmus, B. altitudinus } \\
\text { Paenibacillus mucilaginosus }\end{array}$ & $\begin{array}{l}{[170]} \\
{[171]}\end{array}$ \\
\hline Orange (Citrus sinensis) & B. circulans & [172] \\
\hline Rice (Oryza sativa) & $\begin{array}{l}\text { P. agglomerans, Rahnella aquatilis, } P \text {. } \\
\text { orientalis } \\
\text { Pantoea ananatis, Rahnella aquatilis, } \\
\text { Enterobacter sp. } \\
\text { Not identified } \\
\text { Not specified }\end{array}$ & $\begin{array}{l}{[77]} \\
{[114]} \\
{[161]} \\
{[73]}\end{array}$ \\
\hline Sugarcane (Saccharum officinarum L) & $\begin{array}{l}\text { Not mentioned } \\
\text { Not specified }\end{array}$ & $\begin{array}{l}{[173]} \\
{[73]}\end{array}$ \\
\hline $\begin{array}{l}\text { Various leguminous and non-leguminous } \\
\text { plants }\end{array}$ & $\begin{array}{l}\text { Azotobacter sp., Mesorhizobium sp., Pseudomonas sp., } \\
\text { Bacillus sp., Rhizobium sp. }\end{array}$ & [149] \\
\hline
\end{tabular}

According to Meena et al. [176], KSB are precious resources for mitigating K-deficiencies in agricultural soils but experimental evidence on their efficacy at the field level is still grossly inadequate. Certainly, more research is needed to increase their usability. This and related information will certainly help in understanding their use as bioinoculants for practical purposes under actual field conditions [180].

\subsubsection{Zinc solubilizers}

Zinc is a major plant micronutrient that drives several primary and secondary metabolic processes [181]. Existing reports worldwide show that $\mathrm{Zn}$ deficiency is a common problem in most agricultural soils due to nutrient mining during crop harvesting and increased use of NPK fertilizers containing lesser amounts of these micronutrients [182,183]. Synthetic Zn fertilizers are often employed to augment these deficiencies at the recommended rates of approximately $25 \mathrm{~kg} \mathrm{ha}^{-1} \mathrm{ZnSO} 4$ heptahydrate, (equivalent to $5 \mathrm{~kg} \mathrm{ha}^{-1} \mathrm{Zn}$ ). Nevertheless, these artificial fertilizers are not costeffective and readily get converted into insoluble and non-accessible forms to plants [183,184].

Recent literature advances rhizobacterial Zn solubilization [149,185-187]. In a study by Naz et al. [188], species of Azospirillum, Azotobacter, Pseudomonas, and Rhizobium species have been shown to significantly increase $\mathrm{Zn}$ uptake in wheat plants relative to un-inoculated controls. Similarly, Sharma et al. [189] who isolated 134 Bacillus strains from soybean (G. max) rhizosphere soils to select for effective $\mathrm{Zn}$ solubilizers showed that the isolates significantly increased the $\mathrm{Zn}$ concentration of 
inoculated crops relative to the un-inoculated controls. Similarly, several $\mathrm{Zn}$ solubilizing bacteria (ZSB) including P. fragi, Pantoea dispersa, P. agglomerans, E. cloacae, and Rhizobium sp. isolated from wheat and sugarcane were recently shown to improve the $\mathrm{Zn}$ contents and growth of pot-grown wheat [190]. In another study, Dinesh et al. [191] several promising ZSB isolated from soil were evaluated for their effects on soil $\mathrm{Zn}$ release rates, soil-available $\mathrm{Zn}$ and plant $\mathrm{Zn}$ contents in a greenhouse experiment and the results showed that $\mathrm{Zn}$ concentration in soil and plants was higher in the treated plants than the non-treated controls. In another study in India by Goteti et al. [181], the bacterization of maize seeds with a $\mathrm{Zn}$-solubilizing Pseudomonas strain significantly enhanced the uptake and concentration of $\mathrm{Zn}$ in pot experiments.

Prospective ZSB for enhanced Zn uptake in maize, Zn solubilizing Bacillus strains that modulate the growth, yield, and $\mathrm{Zn}$ biofortification in soybean and wheat have also been reported in India [192]. In a study by Sunithakumari et al. [193], several rhizobacteria isolated from banana, chilli, bean, groundnuts, maize, sorghum, and tomato plants among them, species of Stenotrophomonas, Mycobacterium, Enterobacter, Pseudomonas, and Xanthomonas also demonstrated excellent in vitro $\mathrm{Zn}$ solubilization abilities. Agrobacterium tumefaciens and Rhizobium sp. isolated from barley and tomato have also been demonstrated to solubilize $\mathrm{Zn}$ in vitro [194]. Zinc solubilizing abilities and increased Zn uptake following inoculation of rice plants by Pseudomonas strains [195], soybean and wheat by $B$. aryabhattai [196], maize by Bacillus strains [197], wheat by Serratia liquefaciens, S. marcescens, and B. thuringiensis [198] and recently in rice by several ZSB [199] have similarly been demonstrated. It is proposed that the use of such ZSB in the field can result in increased Zn uptake by plants, and subsequently, improved growth and yield [200].

\subsubsection{Iron sequesters}

Iron is the $4^{\text {th }}$ most abundant nutrient element in soil and an important micronutrient needed for plant growth [201]. Most agricultural soils are however Fe-deficient especially since the element occurs in the insoluble ferric $\left(\mathrm{Fe}^{3+}\right)$ form that is unavailable for plant-uptake [202]. Thus, the unavailability of Fe is a major plant-growth limiting factor in many agricultural systems [34,203].

Some microorganisms have developed special mechanisms for Fe-acquisition by synthesizing low molecular weight metabolites known as siderophores [142] with high affinity for Fe in low-Fe environments [204,205]. This way, the siderophores function as Fe-chelators and bind most of the available $\mathrm{Fe}$ in the rhizosphere [34]. Furthermore, literature advances that siderophore-producing bacteria and the subsequent Fe-unavailability in plant rhizospheres may also prevent the proliferation of plant pathogens [206,207].

A lot of studies have shown the ability of different rhizobacterial species to produce siderophores and the enhancement of plant Fe nutrition. In a recent study by Emami et al. [134], several rhizobacterial isolates from the wheat including Stenotrophomonas sp., Serratia marcescens, Pseudomonas sp., Nocardia fluminea, Stenotrophomonas maltophilia, Bacillus zhangzhouensis, Pseudomonas mosselii, and Microbacterium sp. were shown to have very good siderophore production abilities in vitro and significantly enhanced the Fe uptake in greenhouse-grown wheat plants. In another recent study by Verma and Pal [149], various rhizobacteria including Bacillus sp., Pseudomonas sp., Rhizobium sp., MEsorhizobium sp., and Azotobacter sp. were isolated from various leguminous and non-leguminous plants and shown tom possess siderophore producing capabilities. In yet another recent study, the use of siderophore-producing bacteria was also shown to significantly enhance $\mathrm{Fe}$ uptake and transport in grains [208]. In earlier studies by Vendan et al. [209], several endophytic rhizobacteria such as Bacillus cereus, B. flexus, B. megaterium, Lysinibacillus fusiformis, L. sphaericus, Microbacterium phyllosphaerae, Micrococcus luteus isolated from maize also exhibited excellent siderophore production abilities. Siderophore-producing rhizobacteria have also been isolated from maize and canola in Iran [210], peach, and pear roots in Turkey [211], corn in Brazil [87], and banana in Kenya [212], among others.

The $\mathrm{Fe}^{3+}$ and microbial siderophores form a complex in the membrane in which the former is reduced to $\mathrm{Fe}^{2+}$ and released into the cell through an input mechanism that links the outer and inner cell membranes. During this process, the siderophores can be destroyed or recycled [213] and the 
plants can access and assimilate the $\mathrm{Fe}^{2+}$ from bacterial siderophores by direct up-take of the Fesiderophore complexes or by exchange reactions using appropriate ligands [214,215]. Siderophore production is a classic example of how rhizobacterial inoculants in biofertilizers can establish themselves in the plant rhizosphere and enhance Fe nutrition and due to its indisputable importance, should be given more attention [216].

\section{The current state of plant growth-promoting rhizobacterial biofertilizers and crop production}

There is a burgeoning volume of literature demonstrating the application of microbial products as biofertilizers and agricultural inputs [100]. Around 170 organizations in 24 countries are engaged in the commercial production of biofertilizers and many countries have industries that produce, market, and distribute microbe-based fertilizers at both large and small scales [217]. The commercial production and utilization of rhizobial inoculants have been practiced for many decades now, partially reducing the need for mineral fertilizers in many countries [58]. However, the full potential of several beneficial rhizobacteria as biofertilizers remains largely unexplored.

Unlike the rhizobial inoculants, PSB like Bacillus and Pseudomonas, and diazotrophs like Azospirillum have less frequently been used and on a much lesser scale than the rhizobial inoculants and it is estimated that no more than a few thousand hectares are treated annually with non-rhizobial biofertilizers [33]. Most of the currently available non-rhizobial PGPR inoculants consist of Azospirillum as free-living N2 fixers or Bacillus as PSB [32]. According to Lesuer [33], the application of commercial non-rhizobial biofertilizers does not significantly affect global food production. This is probably because of the several bottlenecks that exist in their uptake and use in contrast to their well-documented PGP roles. The global agricultural crop production was estimated at 1.6 billion hectares [218], but there is an obvious lack of market penetration and application of non-rhizobial biofertilizers despite decades of research [33].

Generally, the commercialization of biofertilizers remains low globally but is steadily expanding. By the year 2014, the biofertilizer market represented only about $5 \%$ of the total chemical fertilizer market [219]. In the developed world where agricultural chemicals remain relatively inexpensive, the use of PGPR occupies a smaller niche, but this is also growing [100]. The global biofertilizer market is currently largely dominated by legume and $\mathrm{N}_{2}$-fixing inoculants [220]. Literature suggests that the rhizobia-based inoculants occupy approximately $78 \%$ of the global biofertilizer market, while P solubilizers and other bioinoculants occupy about 15 and $7 \%$ respectively [221,222]. Recent reports show that $\mathrm{P}, \mathrm{Zn}$, and $\mathrm{K}$ based biofertilizers are also emerging as important bioinoculants to address nutrient deficiencies in soils [186,223]. According to Teotia et al. [180], KSM are widely employed as bioinoculants in most countries, where crop fields are K-deficient.

Table 5: Examples of commercial biofertilizer products in some countries around the world

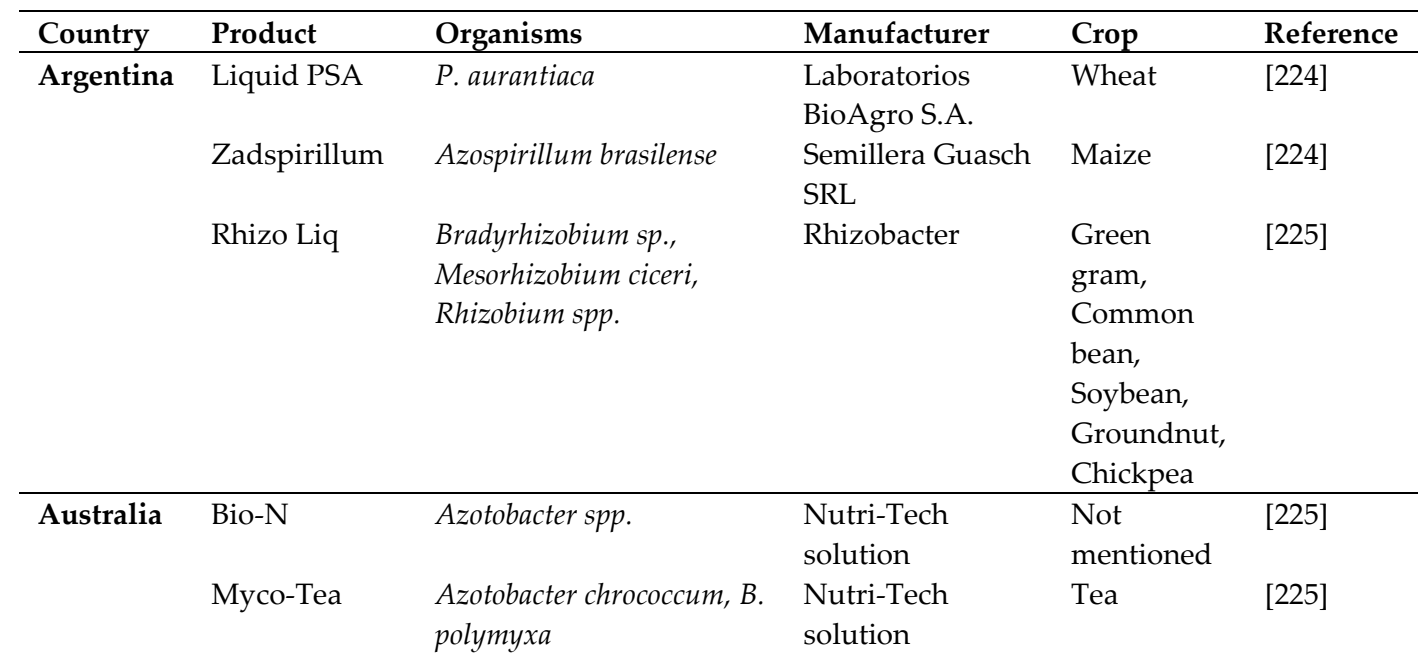




\begin{tabular}{|c|c|c|c|c|c|}
\hline & Twin N & $\begin{array}{l}\text { Azorhizobium sp., } \\
\text { Azoarcus sp., Azospirillum } \\
\text { sp }\end{array}$ & $\begin{array}{l}\text { Mapleton Int. } \\
\text { Ltd }\end{array}$ & $\begin{array}{l}\text { Not } \\
\text { mentioned }\end{array}$ & [225] \\
\hline Brazil & Bioativo & PGPR consortia & Embrafros Ltda & $\begin{array}{l}\text { Beans, } \\
\text { maize, } \\
\text { sugarcane, } \\
\text { rice, cereals }\end{array}$ & [226] \\
\hline \multirow[t]{2}{*}{ Canada } & $\begin{array}{l}\text { Rhizocell GC } \\
\text { Nodulator }\end{array}$ & $\begin{array}{l}\text { B. amyloliquefaciens IT } 45 \\
\text { B. japonicum }\end{array}$ & $\begin{array}{l}\text { Lallen and plant } \\
\text { care BASF Inc. }\end{array}$ & $\begin{array}{l}\text { Beans, } \\
\text { maize, } \\
\text { carrot, rice, } \\
\text { cotton }\end{array}$ & [226] \\
\hline & Vault HP & Bradyrhizobium sp. & BASF & $\begin{array}{l}\text { Not } \\
\text { mentioned }\end{array}$ & [225] \\
\hline China & $\mathrm{CBF}$ & $\begin{array}{l}\text { Bacillus mucilaginosus, } B \text {. } \\
\text { subtilis }\end{array}$ & $\begin{array}{l}\text { China Bio- } \\
\text { Fertilizer AG }\end{array}$ & $\begin{array}{l}\text { Various } \\
\text { cereals }\end{array}$ & [224] \\
\hline Colombia & Fe Sol B & Not mentioned & $\begin{array}{l}\text { Agri Life Bio } \\
\text { Solutions }\end{array}$ & $\begin{array}{l}\text { Not } \\
\text { mentioned }\end{array}$ & [227] \\
\hline Germany & $\begin{array}{l}\text { FZB } 24 \mathrm{fl}, \\
\text { BactofilA } 10\end{array}$ & $\begin{array}{l}\text { B. amyloliquefaciens, } B \text {. } \\
\text { megaterium, } P \text {. fluorescens }\end{array}$ & AbiTEP GmbH & $\begin{array}{l}\text { Vegetables, } \\
\text { cereals }\end{array}$ & {$[226]$} \\
\hline Hungary & BactoFil A10 & $\begin{array}{l}\text { A. brasilense, Azotobacter } \\
\text { vinelandii, B. megaterium }\end{array}$ & AGRObio & Maize & [228] \\
\hline \multirow[t]{4}{*}{ India } & $\begin{array}{l}\text { Ajay } \\
\text { Azospirillum }\end{array}$ & Azospirillum & Ajay Biotech & Cereals & [224] \\
\hline & $\begin{array}{l}\text { Greenmax } \\
\text { AgroTech } \\
\text { Life } \\
\text { Biomix, } \\
\text { Biodinc, G } \\
\text { max PGPR }\end{array}$ & Azotobacter, P. fluorescens & Biomax & $\begin{array}{l}\text { Various } \\
\text { crops }\end{array}$ & [226] \\
\hline & Fe Sol B & Not mentioned & $\begin{array}{l}\text { Agri Life Bio } \\
\text { Solutions }\end{array}$ & $\begin{array}{l}\text { Not } \\
\text { mentioned }\end{array}$ & [227] \\
\hline & $\begin{array}{l}\text { Symbion van } \\
\text { plus }\end{array}$ & B.megaterium & $\begin{array}{l}\text { T. stanes and Co. } \\
\text { Ltd }\end{array}$ & $\begin{array}{l}\text { Not } \\
\text { mentioned }\end{array}$ & [229] \\
\hline Kenya & Biofix & Rhizobia & $\begin{array}{l}\text { MEA Fertilizer } \\
\text { Ltd }\end{array}$ & $\begin{array}{l}\text { Not } \\
\text { mentioned }\end{array}$ & {$[225,230]$} \\
\hline Nigeria & Nodumax & Bradyrhizobia & IITA & $\begin{array}{l}\text { Not } \\
\text { mentioned }\end{array}$ & {$[225,231]$} \\
\hline Russia & Azobacterium & Azobacterium brasilense & $\begin{array}{l}\text { JSC Industrial } \\
\text { Innovations }\end{array}$ & $\begin{array}{l}\text { Wheat, } \\
\text { barley, } \\
\text { maize, }\end{array}$ & [224] \\
\hline \multirow[t]{7}{*}{$\begin{array}{l}\text { South } \\
\text { Africa }\end{array}$} & Organico & $\begin{array}{l}\text { Bacillus spp. Enterobacter } \\
\text { spp., Pseudomonas, } \\
\text { Stenotrophomonas, } \\
\text { Rhizobium }\end{array}$ & $\begin{array}{l}\text { Amka Products } \\
\text { (Pty) Ltd }\end{array}$ & $\begin{array}{l}\text { Not } \\
\text { mentioned }\end{array}$ & [225] \\
\hline & $\begin{array}{l}\text { Azo-N, Azo- } \\
\text { N-Plus }\end{array}$ & A.brasiliense, A. lipoferum & $\begin{array}{l}\text { Biocontrol } \\
\text { Products Ltd }\end{array}$ & $\begin{array}{l}\text { Not } \\
\text { mentioned }\end{array}$ & {$[232,233]$} \\
\hline & $\begin{array}{l}\text { Lifeforce, } \\
\text { Firstbase, } \\
\text { Biostart, } \\
\text { Landbac, } \\
\text { Composter, } \\
\text { Waterbac }\end{array}$ & Bacillus spp., & $\begin{array}{l}\text { Microbial } \\
\text { solution (Pty) } \\
\text { Ltd }\end{array}$ & $\begin{array}{l}\text { Not } \\
\text { mentioned }\end{array}$ & {$[153,155]$} \\
\hline & Histick & B. japonicum & BASF & $\begin{array}{l}\text { Not } \\
\text { mentioned }\end{array}$ & [231] \\
\hline & N-Soy & B.jаропіист & $\begin{array}{l}\text { Biocontrol } \\
\text { Products Ltd }\end{array}$ & $\begin{array}{l}\text { Not } \\
\text { mentioned }\end{array}$ & {$[231]$} \\
\hline & Soilfix & $\begin{array}{l}\text { Brevibacillus laterosporus, } \\
\text { Paenibacillus chitinolyticus }\end{array}$ & $\begin{array}{l}\text { Biocontrol } \\
\text { Products Ltd }\end{array}$ & $\begin{array}{l}\text { Not } \\
\text { mentioned }\end{array}$ & [234] \\
\hline & Organico & Bacillus sp. & Amka Products & $\begin{array}{l}\text { Not } \\
\text { mentioned }\end{array}$ & [232] \\
\hline
\end{tabular}




\begin{tabular}{|c|c|c|c|c|c|}
\hline & Bac-up & B. subtilis & $\begin{array}{l}\text { Biocontrol } \\
\text { Products Ltd }\end{array}$ & $\begin{array}{l}\text { Not } \\
\text { mentioned }\end{array}$ & [225] \\
\hline \multirow[t]{2}{*}{ Spain } & InomixR & B. polymyxa, B. subtilis & Lab (Labiotech) & Cereals & [226] \\
\hline & Vita Soil & PGPR consortia & Symborg & $\begin{array}{l}\text { Not } \\
\text { mentioned }\end{array}$ & [229] \\
\hline Thailand & BioPlant & $\begin{array}{l}\text { Clostridium, } \\
\text { Achromobacter, } \\
\text { Streptomyces, Aerobacter, } \\
\text { Nitrobacter, Nitrosomonas, } \\
\text { Bacillus }\end{array}$ & $\begin{array}{l}\text { Artemis \& } \\
\text { Angelio Co. Ltd. }\end{array}$ & $\begin{array}{l}\text { Not } \\
\text { mentioned }\end{array}$ & [225] \\
\hline \multirow[t]{3}{*}{$\begin{array}{l}\text { United } \\
\text { Kingdom }\end{array}$} & $\begin{array}{l}\text { Ammnite A } \\
100\end{array}$ & $\begin{array}{l}\text { Azotobacter, Bacillus, } \\
\text { Rhizobium, Pseudomonas }\end{array}$ & $\begin{array}{l}\text { Cleveland } \\
\text { biotech }\end{array}$ & $\begin{array}{l}\text { Cucumber, } \\
\text { tomato, } \\
\text { pepper }\end{array}$ & [226] \\
\hline & Legume Fix & $\begin{array}{l}\text { Rhizobium sp., B. } \\
\text { japonicum. }\end{array}$ & $\begin{array}{l}\text { Legume } \\
\text { Technology }\end{array}$ & $\begin{array}{l}\text { Common } \\
\text { bean, } \\
\text { Soybean }\end{array}$ & [225] \\
\hline & Twin N & $\begin{array}{l}\text { Azorhizobium sp., } \\
\text { Azoarcus sp., Azospirillum } \\
\text { sp }\end{array}$ & $\begin{array}{l}\text { Mapleton Int. } \\
\text { Ltd }\end{array}$ & $\begin{array}{l}\text { Not } \\
\text { mentioned }\end{array}$ & [225] \\
\hline Uruguay & Nitrasec & Rhizobium sp. & Lage y Cia & $\begin{array}{l}\text { Not } \\
\text { mentioned }\end{array}$ & [225]) \\
\hline \multirow[t]{7}{*}{ USA } & Inogro & 30 bacterial species & $\begin{array}{l}\text { FLozyme } \\
\text { Corporation }\end{array}$ & Rice & [224] \\
\hline & Vault NP & B. japonicum & $\begin{array}{l}\text { Becker } \\
\text { Underwood }\end{array}$ & $\begin{array}{l}\text { Not } \\
\text { mentioned }\end{array}$ & [225] \\
\hline & $\begin{array}{l}\text { Chickpea } \\
\text { Nodulator }\end{array}$ & Mesorhizobium cicero & $\begin{array}{l}\text { Becker } \\
\text { Underwood }\end{array}$ & Chickpea & [225] \\
\hline & $\begin{array}{l}\text { Cowpea } \\
\text { Inoculant }\end{array}$ & Rhizobia & $\begin{array}{l}\text { Becker } \\
\text { Underwood }\end{array}$ & Cowpea & [225] \\
\hline & PHC Biopak & $\begin{array}{l}\text { B. azotofixans, } B \text {. } \\
\text { licheniformis, } B \text {. } \\
\text { megaterium, B. polymyxa, } \\
\text { B. subtilis, B. thuringiensis }\end{array}$ & $\begin{array}{l}\text { Plant Health } \\
\text { Care Inc. }\end{array}$ & $\begin{array}{l}\text { Not } \\
\text { mentioned }\end{array}$ & [225] \\
\hline & $\begin{array}{l}\text { Complete } \\
\text { Plus }\end{array}$ & Bacillus strains & $\begin{array}{l}\text { Plant Health } \\
\text { Care }\end{array}$ & $\begin{array}{l}\text { Various } \\
\text { crops }\end{array}$ & [228] \\
\hline & Quickroots & B. amyloliquefaciens & Monsanto & $\begin{array}{l}\text { Wheat and } \\
\text { common } \\
\text { bean }\end{array}$ & [224] \\
\hline
\end{tabular}

In this regard, India is reportedly the fourth-largest consumer of $\mathrm{K}$ bioinoculants in the world, whereas countries like the USA, China, and Brazil top the list in total consumption of these microbial products [235].

In 2013, North America had the highest demand for biofertilizers geographically and projections were that the entire Asia-Pacific biofertilizer market would show the maximum growth from 2014 to 2019 and dominate the global biofertilizer market in terms of demand [236]. The biofertilizer market is clearly undergoing a global expansion due to the need to increase food production sustainably [107]. Forecasts predict that the biofertilizer market share will reach USD 1.66 billion by 2022 and will rise at a compounding annual growth rate (CAGR) of 13.2\% from 2015 to 2022 and according to Market Data Forecast [237], the current global market of microbial inoculants was estimated at USD 396.07 million in 2018 and expected to rise at an annual growth rate of 9.5\% to approximately USD 623.51 million by 2023. $\$ 205.6$ million with a CAGR of $6.4 \%$ between 2011 and 2018 [100].

In the USA and Canada alone, legume biofertilizers were the largest revenue earners in 2011, accounting for $72.5 \%$ of the total revenue collection from biofertilizers, with an expected CAGR of approximately $5.3 \%$ up to 2018 . This advancement has also stimulated the isolation and selection of biofertilizers with the best PGP abilities [100]. Table 5 displays examples of commercially-available biofertilizers used to improve crop productivity in various countries across the globe. Although many reports exist on the formulation, commercialization, and application of rhizobacteria in other 
continents, very few reports indicate their commercialization and applications in African countries. Most of these products are commercialized and used in Europe, Asia, and the USA but in Africa, only South Africa conspicuously has the widest commercialization and application. Previous research documents that in most developing countries, the PGPR inoculant technology has little or no impact on crop productivity since it is either not practiced or the available inoculants are of poor quality [238].

The most advanced and prevalent biofertilizer market is Europe, and growth from $\$ 2566.4$ million in 2012 to $\$ 4582.2$ million was observed in this region 2017, at an annual growth rate of $12.3 \%$ from 2012 to 2017 [239]. In 2012, the biofertilizer market was highest in North America and was expected to grow at a rate of $14.4 \%$ from 2013-2018 [240]. The $\mathrm{N}_{2}$-fixing biofertilizers were used in maximum as compared to all other biofertilizers, and in 2012 their worldwide demand increased over $78 \%$ [241]. Several biofertilizer formulations are already in use on a commercial level.

\section{Future prospects and perspectives of plant growth-promoting rhizobacterial biofertilizers and crop production}

The use of biofertilizers as an integral component of agricultural practices is quickly gaining momentum worldwide. These microbial products are already in use successfully in some countries their use is expected to expand [242]. There is an increasing number of studies aiming to isolate, identify, and evaluate the capacity of PGPR with the potential of being transformed into inoculants for a variety of crops [243-246]. It is, therefore, reasonable to expect that soon, the extensive use of biofertilizers will offer various strategies for the overall development of sustainable crop production systems [11]. However, more widespread utilization of biofertilizers will require proper regulatory and legal frameworks that are currently stringent and a hindrance to their proper utilization [247]. Fortunately, the regulatory authorities are of late increasingly encouraging the implementation of alternative crop fertilization mechanisms to promote the development of sustainable agricultural technologies [100]. For instance, acknowledging the need for a specific legislative framework for biofertilizers/biostimulants in Europe, the European Commission subsequently issued a proposal to amend existing regulations [248]. Such initiatives will eventually relax the stringent regulatory frameworks and enable the widespread adoption of these microbial resources.

While a number of the existing biofertilizers are likely to be composed of non-transformed rhizobacterial strains selected for their positive traits, the invention of genetically modified rhizobacterial inoculants which are likely to be more efficient in stimulating plant growth is required. However, the biggest huddle will be for scientists to prove to the general public and regulatory authorities worldwide that genetically-engineered organisms do not present any new hazards or risks [11].

Our current ability to harness the plant microbiome in agriculture and manipulate plant microbiomes in situ remain largely limited, and more trials are needed in this area to increase our understanding and enable their application and commercialization at large scale [249]. The inoculant industry is faced with various challenges in making formulations with prolonged shelf lives. The development of formulations with increased shelf lives, broad spectra of action, and consistent field performance could pave the way for the commercialization of this technology at a faster rate [250]. In this regard, new biotechnological approaches should be evaluated to develop formulations with longer shelf lives. Micro-encapsulation is one viable approach but most of the experiments on this have been restricted only to laboratories and the technology should be standardized for the industrial and field applications [217]. The future of biofertilizer technology depends a lot on developing efficient PGP strains. This is quite challenging but continued research in this area will eventually pave way for this [251].

Research on N-fixation and Pm solubilization by PGPRs is progressing well, but research on $\mathrm{K}$ solubilization is not progressing as fast yet this is the $3^{\text {rd }}$ most important macronutrient for plant development [252]. Research in this area will not only promote the use of bioinoculants but also create confidence in their utilization. Apart from this, future research should focus on the optimization of cost-effective growth conditions, can tolerate unfavorable environmental situations, and achieve 
higher productivity [253]. The potential benefits of microbial biofertilizers in stressful soil environments should especially be explored for applicability especially in the wake of climate change and global warming. More research is needed on the practical aspects of mass production and formulation to develop effective, stable, safer, cheap, and novel bioformulations. The use of consortia of multi-trait PGP strains may be useful in obtaining novel biofertilizers that can offer inexpensive substitutes for agrochemicals [252,254,255].

The use of nano-factories is an emerging technique in bioformulation development in which engineered bioinoculants are used to enhance communication with plants through quorum sensing that leads to biofilm formation. Biofilm formation not only maintains a sufficient bacterial population in soil but also protects the bioinoculant from fluctuating environmental conditions and provides them a competitive advantage [256]. The interactions among plants, and microorganisms as biofertilizers may need further studies [36], and future strategies also are needed to focus on understanding the interactions of biofertilizers from bacteria with nanoparticles, which also serve as useful micronutrients for microorganisms and plants [36].

Future research should also include careful isolation of the rhizosphere microbiota, and their in situ testing for use as plant inoculants [249]. It is prospected that the identification of effective microbiomes in different soil types and climates will extremely be helpful in this regard [257]. To improve this strategy, establishing a global database of effective plant microbiomes will be an important milestone towards successful translational research [249]. The present international market for organically produced food is approximately US\$30 billion and is increasing at about $8 \%$ annually with approximately 37.2 million hectares of land being under organic-based agriculture technology [258]. However, only about $1 \%$ of the world's agriculture comprises organic methods, an indication of the remarkable prospects and capacity in the growth of biofertilizers [217]. A lot of obstacles still remain to be overcome before this can fully be realized. For instance, numerous formulations based on such microorganisms have been developed, with applications for different crops around the world (Saleem and Khan, 2017). However, the inconsistency in the results obtained, dependent on autochthonous microbiota, available nutrients and crop characteristics, makes it necessary to optimize each particular system [254].

The use of biotechnological tools and improvement in regulations can go a long way in designing a rhizobial bioformulation that will be more reliable and effective. To design a tailor-made state of the art rhizobial formulation, it is very important to further our knowledge on plant-microbe interactions by using the latest tools and techniques. Use of omics-based approaches (genomics and proteomics) can also be very useful in enhancing our understanding of plant-microbial symbioses and omics-based techniques including genomics, proteomics and metabolomics can go a long way in designing state of the art bioformulation for a particular soil and crop [59].

\section{Conclusions}

The greatest global challenge in the $21^{\text {st }}$ century is to develop and implement sustainable agricultural practices. This can only be achieved if we accommodate changing and advanced technologies such as the use of efficient rhizobacterial biofertilizers. The discussion in this chapter will definitely be useful for the development of sustainable agro-ecosystems. The use of these bioresources though has been practiced in several parts of the globe is still low but the results are encouraging and there is room for improvement to enhance their efficacy. With time, the practice will certainly grow and projections are that in the coming years, the bioformulations demand will have huge market potential. Researchers, agricultural institutions, and universities can fast-track biofertilizer development and promote their usage and adaptation for sustainable agricultural practices. In addition to these emerging approaches, if issues linked to regulatory and policy development, and social acceptability of microbial/ microbiome products can be simultaneously addressed, these bio-based tools can potentially contribute significantly to the sustainable increase in agricultural productivity 
Author Contributions: Conceptualization, B.A.N, and B.A.M.; writing-original draft preparation, B.A.N.; writing - review and editing, B.A.M., and E.R.M.. All authors have read and agreed to the published version of the manuscript.

Funding: This research received no external funding.

Conflicts of Interest: The authors declare no conflict of interest.

\section{References}

1. Rani, U.; Kumar, V. Microbial Bioformulations: Present and Future Aspects. In Nanobiotechnology in Bioformulations; Prasad, R., Kumar, V., Choudhary, D., Eds.; Nanobiotechnology in the Life Sciences; Springer: Cham, 2019; pp. 243-258.

2. Ahkami, A.H.; White, R.A.I.; Handakumbura, P.P.; Jansson, C. Rhizosphere engineering: enhancing sustainable plant ecosystem productivity. Rhizosphere 2017, 3, 233-243.

3. Meena, V.S.; Meena, S.K.; Verma, J.P.; Kumar, A.; Aeron, A.; Mishra, P.K.; Bisht, J.K.; Pattanayaka, A.; Naveed, M.; Dotaniya, M.L. Plant beneficial rhizospheric microorganism (PBRM) strategies to improve nutrients use efficiency: a review. Ecol. Eng. 2017, 8-32.

4. Bhat, M.A. Plant growth promoting rhizobacteria (PGPR) for sustainable and eco-friendly agriculture. Acta Sci. Agric. 2019, 3, 23-25.

5. Kunawat, K.; Sharma, P.; Sirari, A.; Singh, U.; Saharan, K. Synergism of Pseudomonas aeruginosa (LSE2) nodule endophyte with Bradyrhizobium sp. (LSBR-3) for improving plant growth, nutrientt acquisition and soil health in soybean. World J. Biotechnol. 2019, 35, 47.

6. Potassium solubilizing microorganisms for Sustainable Agriculture; Meena, V.S., Maurya, B.R., Verma, J.P., Verma, R.S., Eds.; Springer: India, 2016;

7. Chaudhary, S.; Dheri, G.S.; Brar, B.S. Longterm effects of NPK fertilizers and organic manures on carbon stabilization and management index under rice-wheat cropping system. Soil Tillage Res. 2017, 166, 59-66.

8. Ding, J.; Jiang, X.; Guan, D.; Zhao, B.; Ma, M.; Zhou, B.; Cao, F.; Yang, X.; Li, L.; Li, J. Influence of inorganic fertilizer and organic manure application on fungal communities in along-term field experiment of Chinese Mollisols. Appl. Soil Ecol. 2017, 111, 114-122.

9. Aloo, B.N.; Makumba, B.A.; Mbega, E.R. The potential of Bacilli rhizobacteria for sustainable crop production and environmental sustainability. Microbiol. Res. 2019, 219, 26-39, doi:10.1016/j.micres.2018.10.011.

10. Tomer, S.; Suyal, D.C.; Goel, R. Biofertilizers: A Timely Approach for Sustainable Agriculture. In PlantMicrobe Interaction: An approach to Sustainable Agriculture; Choudhary, D.K., Ed.; Springer Nature: Singapore, 2016; pp. 375-395.

11. Mahanty, T.; Bhattacharjee, S.; Goswami, M.; Bhattacharyya, P.N.; Das, B.; Gosh, A.; Tribedi, P. Biofertilizers: a potential approach for sustainable agriculture development. Environmental Science Pollution Research 2017, 24, 3315-3335, doi:10.1007/ s11356-016-8104-0.

12. Schlesinger, W.H. On the fate of anthropogenic nitrogen. Proc. Natl. Acad. Sci. USA 2008, 106, $203-208$.

13. Steffen, W.; Richardson, K.; Rockstrom, J.; Cornell, S.E.; Fetzer, I.; Bennett, E.M. Planetary boundaries: guiding human development on a changing planet. Science 2015, 347, 1259855, doi:10.1126/science.1259855.

14. Di Benedetto, N.A.; Corbo, M.R.; Campaniello, D.; Cataldi, M.P.; Bevilacqua, A.; Sinigaglia, M.; Flagella, $Z$. The role of Plant Growth Promoting Bacteria in improving nitrogen use efficiency for sustainable crop production: a focus on wheat. AIMS Microbiol. 2017, 3, 413-434. 
15. Duarte, C.M.; Alonso, S.; Benito, G.; Montes, C.; Pardo, B.M.; Rios, A.F.; Simo, R.; Valladares, F. Global change. Impact of human activity on the Earth system 2006.

16. Hungria, M.; Nogueira, M.A.; Araujo, R.S. Co-inoculation of soybeans and common beans with Rhizobia and Azospirilla: Strategies to improve sustainability. Biol. Fertil. Soils 2013, 49, 991-801.

17. Mendes, R.; Kruijit, M.; de Bruijn, I.; Dekkers, E.; van der Voort, M.; Scneider, J.H.; Piceno, Y.M.; DeSantis, T.Z.; Andersen, G.L.; Bakker, P.A.; et al. Deciphering the rhizosphere microbiome for diseasesuppressive bacteria. Science 2011, 332, 1097-1100.

18. Ghany, T.A.M.; Alawlaqi, M.M.; Al Abboud, M.A. Role of biofertilizers in agriculture: a brief review. Mycopath 2013, 11, 95-101.

19. Simarmata, T. Tropical bioresources to support biofertilizer industry and sustainable agriculture in Indonesia 2013.

20. Mazid, M.; Khan, T. Future of Bio-fertilizers in Indian agriculture: An Overview. Int. J. Agric. Food. Res. 2014, 3, 10-23.

21. Vessey, J.K. Plant growth promoting rhizobacteria as biofertilizers. Plant Soil 2003, 255, 571-568.

22. Malusá, E.; Vassilev, N. A contribution to set a legal framework for biofertilisers. Appl. Microb. Biotechnol. 2014, 98, 6599-6607, doi:10.1007/s00253-014-5828-y.

23. Pandey, V.; Chandra, K. Agriculturally Important Microorganisms as Biofertilizers: Commercialization and Regulatory Requirements in Asia. In Agriculturally Important Microorganisms: Commercialization and Regulatory Requirements in Asia; Singh, H.B., Sarma, B.K., Keswani, C., Eds.; Springer: Singapore, 2016; pp. 133-145.

24. Bisen, K.; Keskwani, C.; Mishra, S.; Saxena, A.; Rakshit, A.; Singh, H.B. Unrealized potential of seed biopriming for versatile agriculture. In Nutrient use efficiency; from basics to advances; Rakshit, A., Singh, H.B., Sen, Eds.; Springer: India, 2015; pp. 193-206.

25. Sahu, P.K.; Brahmaprakash, G.P. Formulations of Biofertilizers - Approaches and Advances. In Functional Applications; Singh, D.P., Singh, H.B., Prabha, R., Eds.; Microbial Inoculants in sustainable Agricultural Productivity; Springer: New Delhi, 2016; Vol. 2, pp. 179-198.

26. Simarmata, T.; Hersanti; Turmuktini, T.; Fitriatin, B.N.; Setiawati, M.R.; Purwanto Application of Bioameliorant and Biofertilizers to Increase the Soil Health and Rice Productivity. HAYATI J. Biosc. 2016, 23, 181-184, doi:10.1016/j.hjb.2017.01.001.

27. Brahmaprakash, G.P.; Sahu, P.K.; Lavanya, G.; Nair, S.S.; Gangaraddi, V.K.; Gupta, A. Microbial Functions of the Rhizosphere. In Plant-Microbe Interactions in Agro-Ecological Perspectives: Volume 1: Fundamental Mechanisms, Methods and Functions; Singh, D.P., Singh, H.B., Prabha, R., Eds.; Springer: Singapore, 2017; pp. 177-210.

28. Kumar, V. Characterization, Bio-formulation Development and shelf-life studies of locally isolated Biofertilizer strains. Oct. J. Environ. Res. 2014, 2, 32-37.

29. Bharadwaj, D.P.; Ansari, M.W.; Sahoo, R.K.; Tuteja, N. Biofertilizers function as key player in sustainable agriculture by improving soil fertility, plant tolerance and crop productivity. Microbial Cell Fact. 2014, 13, 66.

30. Brahmaprakash, G.P.; Sahu, P.K. Biofertilizers for sustainability. J. Indian Inst. Sci. 2012, 92, 37-62.

31. Tittabutr, P.; Payakapong, W.; Teaumroong, N.; Singleton, P.W.; Boonkerd, N. Growth, survival and field performance of bradyrhizobial liquid inoculant formulations with polymeric additives. Sci. Asia 2007, 33, 69-77. 
32. Herrmann, L.; Lesueur, D. Challenges of formulation and quality of biofertilizers for successful inoculation. Appl. Microb. Biotechnol. 2013, 97, 8859-8873.

33. Lesueur, D.; Deaker, R.; Herrmann, L.; Bräu, L.; Jansa, J. The Production and Potential of Biofertilizers to improve Crop Yields. In Bioformulations for Sustainable Agriculture; Arora, N.K., Menhaz, S., Balestrini, R., Eds.; Springer: New Delhi, 2016; pp. 71-92.

34. Singh, M.; Singh, D.; Gupta, A.D.; Pandey, K.D.; Singh, K.P.; Kumar, A. Plant Growth Promoting Rhizobacteria. In PGPR Amelioration in Sustainable Agriculture; Elsevier, 2019; pp. 41-66.

35. Arora, N.K.; Maheshwari, D.K.; Khare, E. Plant growth promoting rhizobacteria: constraints in bioformulation, commercialization and future strategies. In Bacteria and plant health; Maheshwari, D.K., Ed.; Springer: Berlin, 2010; pp. 97-116.

36. El-Ghamry, A.; Mosa, A.A.; Alshaal, T.; El-Ramady, H. Nanofertilizers vs. Biofertilizers: New Insights. Environ. Biodivers. Soil Sec. 2018, 2, 51-72, doi:10.21608/jenvbs.2018.3880.1029.

37. Bhattacharyya, P.N.; Jha, D.K. Plant growth-promoting rhizobacteria (PGPR): emergence in agriculture. Microbial. Biotechnol. 2012, 28, 1327-1350.

38. Kumar, A. Phosphate solubilizing bacteria in agriculture biotechnology: diversity, mechanism and their role in plant growth and crop yield. Int. J. Adv. Res. 2016, 4, 116-124.

39. Glick, B.R. Bacteria with ACC deaminase can promote Plant growth and help to feed the world. Microbiol. Res. 2014, 169, 30-39.

40. Suyal, D.C.; Soni, R.; Sai, S.; Goel, R. Microbial inoculants as biofertiliser. In Microbial Inoculants in Sustainable Agricultural Productivity; Singh, D., Prabha, R., Eds.; Springer: New Delhi, 2016; pp. 311-318.

41. Pérez-Montaño, F.; Alías-Villegas, R.; del Cerro, P.; Espuny, M.; Jiménez-Guerrero, I.; Cubo, T. Plant growth promotion in cereal and leguminous agricultural important plants: From microorganism capacities to crop production. Microbiol. Res. 2014, 169, 325-336, doi:https://doi.org/10.1016/j.micres.2013.09.011.

42. Bashan, Y.; de-Bashan, L.E.; Prabhu, S.R.; Hernandez, J.P. Advances in plant growth-promoting bacterial inoculant technology: Formulations and practical perspectives (1998-2013). (A Marschner Review). Plant Soil 2014, 378, 1-33.

43. Nobbe, F.; Schmid, E.; Hiltner, L.; Hotter, E. Versuche über die Stickstoff-Assimilation von Leguminosen. Landwirtsch. Vers.-Stationen 1891, 39, 327-335.

44. Nobbe, F.; Hiltner, L. Inoculation of the soil for cultivating leguminous plants 1986.

45. Fages, J. An industrial view of Azospirillum inoculants: formulation and application technology. Symbiosis 1992, 13, 15-26.

46. Tang, W.H.; Yang, H. Research and application of biocontrol of plant diseases and PGPR in China. In Plant Growth-Promoting Rhizobacteria - present status and future prospects; Ogoshi, A., Kobayashi, K., Homma, Y., Kodama, F., Kondo, N., Akino, S., Eds.; Faculty of Agriculture, Hokkaido University: Japan, 1997; pp. 4-9.

47. Catroux, G.; Hartmann, A.; Revellin, C. Trends in rhizobial inoculant production and use. Plant Soil 2001, 230, 21-30.

48. Deaker, R.; Roughley, R.; Kennedy, I.R. Legume seed inoculation technology - a review. Soil Biol. Biochem. 2004, 36, 1275-1288.

49. Caron, A. Culture of bacteria. Albert Caron of Haus Ellenbach, Germany, Assignor to the Farbenfabriken of Elberfeld Co. Serial no. 656404. 1897.

50. Kolbe, W. Bakterien und Brache im Haushalt der Natur; Koble, B.W.A., Ed.; Springer: Berlin Verlag, 1993; 
51. Suslow, T.V.; Kloepper, J.W.; Schroth, M.N.; Burr, T.J. Beneficial bacteria enhance plant growth. Carlifornia Agriculture 1979, 33, 15-17.

52. Kloepper, J.W.; Schroth, M.N.; Miller, T.D. Effects of rhizosphere colonization by plant-growthpromoting rhizobacteria on potato plant development and yield. Phytopathology 1980, 70, 1078-1082.

53. Kloepper, J.W.; Leong, J.; Teintze, M.; Schroth, M.N. Enhanced plant growth by siderophores produced by plant growth-promoting rhizobacteria. Nature 1980, 286, 885-886.

54. Cooper, R. Bacterial fertilizers in the Soviet Union. Soils and Fertilizers 1959, 22, 327-332.

55. Mishustin, E.N.; Naumova, A.N. Bacterial fertilizers, their effectiveness and mode of action. Mikrobiologiya 1962, 35, 543-555.

56. Phillips, P.W.B. An Economic Assessment of the Global Inoculant Industry. Crop Management 2004, 3, 110, doi:10.1094/CM-2004-0301-08-RV.

57. Jansa, J.; Bationo, A.; Frossard, E.; Rao, I.M. Options for improving plant nutrition to increase common bean productivity in Africa. In Fighting poverty in sub-Saharan Africa: the multiple roles of legumes in integrated soil fertility management; Bationo, A., Waswa, B., Okeyo, J., Maina, F., Kihara, J., Mokwunye, U., Eds.; Springer: Dordrecht, 2011; pp. 201-240.

58. Rodríguez-Navarro, D.N.; Margaret Oliver, I.; Albareda Contreras, M.; Ruiz-Sainz, J.E. Soybean interactions with soil microbes, agronomical and molecular aspects. Agron. Sustain. Dev. 2011, 31, 173190, doi:10.1051/agro/2010023.

59. Arora, N.K.; Verma, M.; Mishra, J. Rhizobial Bioformulations: Past, Present and Future. In Rhizotrophs: Plant Growth Promotion to Bioremediation, Microorganisms for Sustainability; Mehnaz, S., Ed.; Springer Nature: Singapore, 2017; pp. 69-99.

60. Gouda, S.; Kerry, R.G.; Das, G.; Paramithiotis, S.; Patra, J.K. Revitalization of plant growth promoting rhizobacteria for sustainable development in agriculture. Microbiol. Res. 2018, 206, 131-140.

61. Canfield, D.E.; Glazer, A.N.; Falkowski, P.G. The Evolution and Future of Earth's Nitrogen Cycle. Science 2010, 330, 192-196, doi:10.1126/science.1186120.

62. Kliopova, I.; Baranauskaite-Fedorova, I.; Malinauskiene, M.; Staniškis, K. Possibilities of increasing resource efficiency in nitrogen fertilizer production. Clean Technol. Environ. Policy 2016, 18, 901-914.

63. Abdel-Salam, M.A.; Shams, A.S. Feldspar-K fertilization of potato (Solanum tuberosum L.) augmented by biofertilizer. J. Agric. Environ. Sci. 2012, 12, 694-699.

64. Aloo, B.N.; Mbega, E.R.; Makumba, B.A.; Hertel, R.; Danel, R. Molecular identification and in vitro plant growth-promoting activities of culturable Potato (Solanum tuberosum L.) rhizobacteria in Tanzania. Potato Res. 2020, doi:10.1007/s11540-020-09465-x.

65. Naqqash, T.; Hameed, S.; Imram, A.; Hanif, M.K.; Majeed, A.; Van Elsas, J.D. Differential Response of Potato toward inoculation with taxonomically diverse Plant Growth Promoting Rhizobacteria. Front. Plant Sci. 2016, 7, 144, doi:10.3389/fpls.2016.00144.

66. Yousaf, S.; Zohaib, A.; Anjum, S.A.; Tabassum, T.; Abbas, T.; Irshad, S.; Javed, U.; Farooq, N. Effect of Seed Inoculation with Plant Growth Promoting Rhizobacteria on Yield and Quality of Soybean. Pakistan J. Agric. Sci. 2019, 32, 177-184.

67. Htwe, A.Z.; Moh, S.M.; Soe, K.M.; Moe, K.; Yamakawa, T. Effects of Biofertilizer produced from Bradyrhizobium and Streptomyces griseoflavus on plant growth, nodulation, nitrogen fixation, nutrient uptake, and seed yield of Mung Bean, Cowpea, and Soybean. Agronomy 2019, 9, 77, doi:10.3390/agronomy9020077. 
68. Kleingesinds, C.K.; de Santi Ferrara, F.I.; Floh, E.L.S.; Aldar, M.P.M.; Barbosa, H.R. Sugarcane growth promotion by Kosakania sp. ICB117 an endophytic and diazotrophic bacterium. Afr J Microbiol Res. 2018, 12, 105-114, doi:10.5897/AJMR2017.8738.

69. Ahmed, H.F.; Badawy, H.H.; Mahmoud, S.M.; El-Dosouky, M.M. Characterization of Gluconacetobacter diazotrophicus Isolated from Sugarcane (Saccharum officinarum) cultivated in Upper Egypt. Assiut J. Agric. Sci. 2016, 47, 569-582.

70. Suman, A.; Srivastava, A.K.; Gaur, A.; Singh, P.; Singh, J.; Yadav, R.L. Nitrogen use efficiency of sugarcane in relation to its BNF potential and population of endophytic diazotrophs at different $\mathrm{N}$ levels. Plant Growth Regulat. 2008, 54, 1-11.

71. Quecine, M.C.; Araujo, W.L.; Rossetto, P.B.; Ferreira, A.; Tsui, S.; Lacava, P.T.; Mondin, M.; Azevedo, J.L.; Pizzirani-Kleiner, A.A. Sugarcane growth promotion by the endophytic bacterium Pantoea agglomerans 33.1. Appl. Environ. Microbiol. 2012, 78, 7511-7518, doi:10.1128/AEM.00836-12.

72. Wei, C.Y.; Lin, L.; Luo, L.J.; Xing, Y.X.; Hu, C.J.; Yang, L.T.; Li, Y.R.; An, Q. Endophytic nitrogen-fixing Klebsiella variicola strain DX120E promotes sugarcane growth. Biol. Fertil. Soils 2014, 50, 657-666.

73. Oo, K.; Win, T.; Khai, A.; Fu, P. Isolation, Screening and Molecular Characterization of Multifunctional Plant Growth Promoting Rhizobacteria for a Sustainable Agriculture. American Journal of Plant Sciences 2020, 11, 773-792, doi:10.4236/ajps.2020.116055.

74. Shabanamol, S.; Divya, K.; George, T.K.; Rishad, K.S.; Sreekumar, T.S.; Jisha, M.S. Characterization and in planta nitrogen fixation of plant growth promoting endophytic diazotrophic Lysinibacillus sphaericus isolated from rice (Oryza sativa). Physiol. Mol. Plant P. 2018, 102, 46-54, doi:10.1016/j.pmpp.2017.11.003.

75. Pham, V.T.K.; Rediers, H.; Ghequire, M.G.K.; Nguyen, H.H.; De Mot, R.; Vanderleyden, J.; Spaepen, S. The plant growth-promoting effect of the nitrogen-fixing endophyte Pseudomonas stutzeri A15. Arch. Microbiol. 2017, 199, 513-517, doi:10.1007/s00203-016-1332-3.

76. Sev, T.M.; Khai, A.A.; Aung, A.; Yu, S.S. Evaluation of endophytic bacteria from some rice varieties for plant growth promoting activities. J. Sci. Innov. Res. 2016, 5, 144-148.

77. Yaghoubi, K.M.; Pirdashti, H.; Rahimian, H.; Nematzadeh, G.; Ghajar, S.M. Nutrient use efficiency and nutrient uptake promoting of rice by potassium solubilizing bacteria (KSB). Cereal Res. Commun. 2018, $46,1-12$.

78. Mwajita, M.R.; Murage, H.; Tani, A.; Kahangi, E.M. Evaluation of rhizosphere, rhizoplane and phyllosphere bacteria and fungi isolated from rice in Kenya for plant growth promoters. SpringerPlus 2013, 2, 606.

79. Ji, S.H.; Gururani, M.A.; Chun, S.C. Isolation and characterization of plant growth promoting endophytic diazotrophic bacteria from Korean rice cultivars. Microbiol. Res. 2014, 169, 83-98, doi:10.1016/j.micres.2013.06.003.

80. Choudhary, A.T.M.A.; Kennedy, I.R. Prospects and Potentials for Systems of Biological Nitrogen Fixation in Sustainable Rice Production. Biol. Fertil. Soils 2004, 39, 219-227.

81. Doty, S.L. Nitogen-fixing endophytic bacteria for improved plant growth. In Bacteria in agrobiology: Plant growth responses; Maheshwari, D.K., Ed.; Springer-Verlag: Berlin, Heidelberg, 2011; pp. 183-199.

82. Kuan, K.B.; Othman, R.; Rahim, K.A.; Shamsuddin, Z.H. Plant growth-promoting rhizobacteria inoculation to enhance vegetative growth, Nitrogen fixation and nitrogen remobilization of maize under Greenhouse conditions. PLOS ONE 2016, 11, 1-19. 
83. Akintokun, A.K.; Ezaka, E.; Akintokun, P.O.; Taiwo, L.B. Isolation, Screening and Response of Maize to Plant Growth Promoting Rhizobacteria Inoculants. Sci. Agric. Bohem. 2019, 50, 181-190, doi:10.2478/sab2019-0025.

84. Fox, A.R.; Soto, G.; Valverde, C.; Russo, D.; Lagares Jr, A.; Zorreguieta, A.; Alleva, K.; Pascuan, C.; Frare, R.; Mercado-Blanco, J.; et al. Major cereal crops benefit from biological nitrogen fixation when inoculated with the nitrogen-fixing bacterium Pseudomonas protegens Pf-5 X940. Environ. Microbiol. 2016, 18, 35223534, doi:10.1111/1462-2920.13376.

85. Sandhya, V.; Shrivastava, M.; Ali, S.Z.; Prasad, V.S.K. Endophytes from maize with plant growth promotion and biocontrol activity under drought stress. Russian Agric. Sci. 2017, 43, 22-34.

86. Alves, G.C.; Videira, S.S.; Urquiaga, S.; Reis, V.M. Differential plant growth promotion and nitrogen fixation in two genotypes of maize by several Herbaspirillum inoculants. Plant Soil 2015, 387, 307-321, doi:10.1007/s11104-014-2295-2.

87. Szilagyi-Zecchin, V.J.; Ikeda, A.C.; Hungria, M.; Adamoski, D.; Kava-Cordeiro, V.K.; Glienke, C.; GalliTerasawa, L.V. Identification and characterization of endophytic bacteria from corn (Zea mays L.) roots with biotechnological potential in agriculture. AMB Express 2014, 4, 1-9, doi:https://doi.org/10.1186/s13568-014-0026-y.

88. Jha, Y. Endophytic Bacteria as a Modern Tool for Sustainable Crop Management Under Stress. In Biofertilizers for Sustainable Agriculture and Environment; Giri, B., Prasad, R., Wu, Q.S., Varma, A., Eds.; Springer International Publishing: Cham, 2019; pp. 203-223 ISBN 978-3-030-18933-4.

89. Choudhary, M.; Patel, B.A.; Meena, V.S.; Yadav, R.P.; Ghasal, P.C. Seed bio-priming of green gram with Rhizobium and levels of nitrogen and sulphur fertilization under sustainable agriculture. Legume Res. 2019, 42, 205-210.

90. Dhole, A.; Shelat, H.; Vyas, P.; Jhala, Y.; Bhange, M. Endophytic occupation of legume root nodules by nifH-positive non-rhizobial bacteria, and their efficacy in the groundnut (Arachis hypogaea). Ann. Microbiol. 2016, 66, 1397-1407.

91. Taurian, T.; Anzuay, M.S.; Luduena, L.; Angelini, J.G.; Munoz, V.; Valetti, L.; Fabra, A. Effects of single and co-inoculation with native phosphate solubilising strain Pantoea sp J49 and the symbiotic nitrogen fixing bacterium Bradyrhizobium sp SEMIA 6144 on peanut (Arachis hypogaea L.) growth. Symbiosis 2013, 59, 77-85.

92. Youseif, S.H. Genetic diversity of plant growth promoting rhizobacteria and their effects on the growth of maize plants under greenhouse conditions. Ann. Agric. Sci. 2018, 63, 25-35, doi:10.1016/j.aoas.2018.04.002.

93. Silveira, A.P.D.D.; Sala, V.M.R.; Cardoso, B.N.; Labanca, E.G.; Cipriano, M.A.P. Nitrogen metabolism and growth of wheat plant under diazotrophic endophytic bacteria inoculation. Appl. Soil Ecol. 2016, 107, 313-319, doi:10.1016/j.apsoil.2016.07.005.

94. Romero-Perdon, F.; Abril, J.; Camelo, M.; Mareno-Galvan, A.; Pastrana, I.; Rojas-Tapias, D.; Bonilla, R. Azotobacter chroococcum as a potentially useful bacterial biofertilizer for cotton (Gossypium hirsutum). Effect in reducing N fertilization. Rev. Argent. Microbiol. 2017, 49, 377-383.

95. Karimi, N.; Zarea, M.J.; Mehnaz, S. Endophytic Azospirillum for enhancement of growth and yield of wheat. Environ. Sustain. 2018, 1, 149-158, doi:10.1007/s42398-018-0014-2.

96. Castillo, A.R.; Gerding, M.; Oyarzua, P.; Zagal, E.; Gerding, J.; Fischer, S. Plant growth-promoting rhizobacteria able to improve NPK availability: selection, identification and effects on tomato growth. Chilean Journal of Agricultural Research 2019, 79, 473-485. 
97. Patel, D.H.; Naik, J.H.; Amaresan, N. Synergistic effect of root-associated bacteria on plant growth and certain physiological parameters of banana plant (Musa acuminate). Arch. Agron. Soil Sci. 2017, 64, 10211031, doi:10.1080/03650340.2017.1410703.

98. Ahemad, M.; Kibret, M. Mechanisms and applications of plant growth promoting rhizobacteria: Current perspective. J. King Saud Univ. Sci. 2014, 26, 1-20, doi:10.1016/j.jksus.2013.05.001.

99. Santoyo, G.; Moreno-Hagelsieb, G.; Orozco-Mosqueda, M.C.; Glick, B.R. Plant growth-promoting bacterial endophytes. Microbiol. Res. 2016, 183, 92-99, doi:10.1016/j.micres.2015.11.008.

100. Timmusk, S.; Behers, L.; Muthoni, J.; Muraya, A.; Aronsson, A.C. Perspectives and challenges of microbial application for crop improvement. Front. Plant Sci. 2017, 8, 49.

101. Daman, M.; Kaloori, K.; Gaddam, B.; Kausar, R. Plant growth promoting substances (phytohormones) produced by rhizobacterial strains isolated from the rhizosphere of medicinal plants. Int. J. Pharm. Sci. Rev. 2016, 37, 130-136.

102. da Silva, M.F.; de Souza, A.C.; de Oliveira, P.J.; Xavier, G.R.; Rumjanek, N.G.; de Barros Soares, L.H.; Reis, V.M. Survival of endophytic bacteria in polymer-based inoculants and efficiency of their application to sugarcane. Plant Soil 2012, 356, 231-243.

103. Hungria, M.; Franchini, J.C.; Campo, R.J.; Crispino, C.C.; Moraes, J.Z.; Sibaldelli, R.N.R.; Mendes, I.C.; Arihara, J. Nitrogen nutrition of soybean in Brazil: Contributions of biological N2 fixation and N fertilizer to grain yield. Can. J. Plant Sci. 2006, 86, 927-939, doi:10.4141/P05-098.

104. Melchiorre, M.; de Luca, M.J.; Gonzalez Anta, G.; Suarez, P.; Lopez, C.; Lascano, R.; Racca, R.W. Evaluation of bradyrhizobia strains isolated from field-grown soybean plants in Argentina as improved inoculants. Biol. Fertil. Soils 2011, 47, 81-89, doi:10.1007/s00374-010-0503-7.

105. Unkovich, M.; Baldock, J. Measurement of asymbiotic N2 fixation in Australian agriculture. Soil Biol. Biochem. 2008, 40, 2915-2921.

106. Goswami, D.; Thakker, J.N.; Dhandhukia, P.C. Portraying mechanics of plant growth promoting rhizobacteria (PGPR): a review. Cogent Food Agric. 2016, 2, 1-9.

107. Verma, M.; Mishra, J.; Arora, N.K. Plant Growth-Promoting Rhizobacteria: Diversity and Applications. In Environmental Biotechnology: For Sustainable Future.; Sobti, R., Arora, N.K., Kothari, R., Eds.; Springer: Singapore, 2019; pp. 129-173.

108. Alori, E.T.; Glick, B.R.; Babalola, O.O. Microbial phosphorus solubilization and its potential for use in sustainable agriculture. Front. Microbiol. 2017, 8, 971, doi:10.3389/fmicb.2017.00971.

109. Jorquera, M.A.; Crowley, D.E.; Marschner, P.; Greiner, R.; Fernández, M.T.; Romero, D. Identification of $\beta$-propeller phytase-encoding genes in culturable Paenibacillus and Bacillus spp. from the rhizosphere of pasture plants on volcanic soils. FEMS Microbiol. Ecol. 2011, 75, 163-172, doi:10.1111/j.15746941.2010.00995.

110. Malhorta, H.; Vandana, S.S.; Pandey, R. Phosphorus nutrition: plant growth in response to deficiency and excess. In Plant nutrients and abiotic stress tolerance; Hasanuzzaman, M., Fujita, M., Oku, H., Nahar, K., Hawrylak-Nowak, B., Eds.; Springer: Singapore, 2018; pp. 170-190.

111. Oteino, N.; Lally, R.D.; Kiwanuka, S.; Lloyd, A.; Ryan, D.; Germaine, K.J.; Dowling, D.N. Plant growth promotion induced by phosphate solubilizing endophytic Pseudomonas isolates. Front. Microbiol. 2015, 6,745 .

112. Emami, S.; Alikhani, H.A.; Pourbabaei, A.A.; Etesami, H.; Motashare Zadeh, B.; Sarmadian, F. Improved growth and nutrient acquisition of wheat genotypes in phosphorus deficient soils by plant growth- 
promoting rhizospheric and endophytic bacteria. Soil Sci. Plant Nutr. 2018, 64, 719-727, doi:10.1080/00380768.2018.1510284.

113. Rafi, M.M.; Krishnaveni, M.S.; Charyulu, P.B.B.N. Phosphate-Solubilizing Microorganisms and their emerging Role in Sustainable Agriculture. In Recent Developments in Applied Microbiology and Biochemistry; Buddolla, V., Ed.; Academic Press: Dordrecht, 2019; pp. 223-233 ISBN 978-0-12-816328-3.

114. Bakhshandeh, E.; Pirdashti, H.; Shahsavarpour, L. Phosphate and potassium-solubilizing bacteria effect on the growth of rice. Ecol. Eng. 2017, 103, 164-169.

115. Zeng, Q.; Wu, X.; Wen, X. Identification and characterization of the rhizosphere phosphate solubilizing bacterium Pseudomonas frederiksbergensis JW-SD2 and its plant growth promoting effects on poplar seedlings. Ann. Microbiol. 2017, 67, 219-230.

116. Chhabra, S.; Dowling, D.N. Endophyte-Promoted Nutrient Acquisition: Phosphorus and Iron. In Functional Importance of the Plant Microbiome; Doty, S.L., Ed.; Springer: Cham, 2017; pp. 21-42.

117. Varma, P.K.; Uppala, S.; Pavuluri, K.; Chandra, K.J.; Chapala, M.M.; Kumar, K.V.K. Endophytes: Role and Functions in Crop Health. In Plant-Microbe Interactions in Agro-Ecological Perspectives; Singh, D., Singh, H., Prabha, R., Eds.; Springer: Singapore, 2017; pp. 291-310.

118. Walia, A.; Guleira, S.; Chauhan, A.; Mehta, P. Endophytic Bacteria: Role in Phosphate Solubilization. In Endophytes: Crop Productivity and Protection; Maheshwari, D.K., Annapuma, K., Eds.; Sustainable Development and biodiversity; Springer: Cham, 2017; Vol. 16, pp. 61-93.

119. Shrivastava, M.; Srivastava, P.C.; D'Souza, S.F. Phosphate-Solubilizing Microbes: Diversity and Phosphates Solubilization Mechanism. In Role of Rhizospheric Microbes in Soil; Meena, V., Ed.; Springer: Singapore, 2018; pp. 137-165.

120. Cordell, D.; Drangert, J.O; White, S. The Story of Phosphorus: Global Food Security and Food for Thought. Global Environ. Change 2009, 19, 292-305.

121. Hinsinger, P.; Herrmann, L.; Lesueur, D.; Robin, A.; Trap, J.; Waithaisong, K.; Plassard, C. Impact of roots, microorganisms and microfauna on the fate of soil Phosphorus in the rhizosphere. In Phosphorus metabolism in plants; Plaxton, W.C., Lambers, H., Eds.; Annual Plant Reviews; Wiley: Chichester, 2018; Vol. 48, pp. 377-407.

122. Ingle, K.P.; Padole, D.A. Phosphate solubilizing microbes: an overview. Int. J. Curr. Microbial. Appl. Sci. 2017, 6, 844-852.

123. Abd El-Moaty, N.M.; Khalil, H.M.A.; Gomaa, H.H.; Ismail, M.A.; El-Dougdoug, K.A. Isolation, characterization, and evaluation of multi-trait plant growth promoting rhizobacteria for their growth promoting. Middle East J. Appl. Sci. 2018, 8, 554-566.

124. Hanif, M.K.; Hameed, S.; Imram, A.; Naqqash, T.; Shahid, M.; Van Elsas Isolation and characterization of a $\beta$-propeller gene containing phosphobacterium Bacillus subtilis strain KPS-11 for growth promotion of potato (Solanum tuberosum L.). Front. Microbiol. 2015, 6, 583, doi:10.3389/fmicb.2015.00583.

125. Matos, A.D.M.; Gomez, I.C.P.; Nietsche, S.; Xavier, A.A.; Gomes, W.S.; Dos Santos, N.; Jose, A.; Pereira, M.C.T. Phosphate solubilization by endophytic bacteria isolated from banana trees. An. Acad. Bras. Ciênc. 2017, 89, 2945-2954.

126. Rafique, M.; Sultan, T.; Ortas, I.; Chaudhary, H.J. Enhancement of maize plant growth with inoculation of phosphate-solubilizing bacteria and biochar amendment in soil. Soil Sci. Plant Nutr. 2017, 63, 460-469.

127. Krey, T.; Vassilev, N.; Baum, C.; Eichler-Lobermann, B. Effects of long-term phosphorus application and plant-growth promoting Rhizobacteria on maize phosphorus nutrition under field conditions. Eur. J. Soil Biol. 2013, 55, 124-130, doi:http://dx.doi. org/10.1016/j.ejsobi.2012.12.007. 
128. de Abreu, C.S.; Figueiredo, J.E.F.; Oliveira, C.A.; dos Santos, V.L.; Gomes, E.A.; Ribeiro, V.P.; Lana, U.G.P.; Marriel, I.E. Maize endophytic bacteria as mineral phosphate solubilizers. Genet. Mol. Res. 2017, $16,1-13$.

129. Kuklinsky-Sobral, J.; Araújo, W.L.; Mendes, R.; Geraldi, I.O.; Pizzirani-Kleiner, A.A.; Azevedo, J.L. Isolation and characterization of soybean associated bacteria and their potential for plant growth promotion. Environ. Microbiol. 2004, 6, 1244-1251.

130. Kadmiri, I.M.; Chaouqui, L.; Azaroual, S.E.; Sijilmassi, B.; Yaakoubi, K.; Wahby, I. Phosphate-solubilizing and auxin-producing rhizobacteria promote plant growth under saline conditions. Arabian Journal for Science and Engineering 2018, 43, 3403-3415, doi:10.1007/s13369-017-3042-9.

131. Astriani, M.; Zubaidah, S.; Abadi, A.L.; Suarsini, E. Pseudomonas plecoglossicida as a novel bacterium for phosphate solubilizing and indole-3-acetic acid-producing from soybean rhizospheric soils of East Java, Indonesia. Biodiversitas 2020, 21, 578-586, doi:https://doi.org/10.13057/biodiv/d210220.

132. Zabihi, H.R.; Savaghebi, G.R.; Khavazi, K.; Ganjali, A.; Miransari, M. Pseudomonas bacteria and phosphorous fertilization, affecting wheat (Triticum aestivum L.) yield and P uptake under greenhouse and field conditions. Acta Physiol. Plant. 2011, 33, 145-152, doi:10.1007/s11738-010-0531-9.

133. Sood, G.; Kaushal, R.; Panwar, G.; Dhiman, M. Effect of Indigenous Plant Growth-Promoting Rhizobacteria on Wheat (Triticum aestivum L.) Productivity and Soil Nutrients. Commun. Soil Sci. Plant Anal. 2018, 50, 141-152, doi:10.1080/00103624.2018.1556282.

134. Emami, S.; Alikhani, H.A.; Pourbabaei, A.A.; Etesami, H.; Motessharezadeh, B. Effect of rhizospheric and endophytic bacteria with multiple plant growth promoting traits on wheat growth. Environ. Sci. Pollut. Res. 2019, 26, 29804.

135. Batool, S.; Iqbal, A. Phosphate solubilizing rhizobacteria as alternative of chemical fertilizer for growth and yield of Triticum aestivum (Var. Galaxy 2013). Saudi J. Biol. Sci. 2018, doi:10.1016/j.sjbs.2018.05.024.

136. Nyoki, D.; Ndakidemi, P.A. Effects of phosphorus and Bradyrhizobium japonicum on growth and chlorophyll content of cowpea (Vigna unguiculata (L) Walp). Am. J. Exp. Agric. 2014, 4, 11-20.

137. Silva, J.M.; Santos, T.M.C.; Albuquerque, L.S.; Montaldo, Y.C.; Oliveira, J.U.L.; Silva, S.G.M.; Nascimento, M.S.; Teixeiria, R.R.O. Potential of endophytic bacteria (Herbaspirillum spp. and Bacillus spp.) to promote sugarcane growth. Aust. J. Crop Sci. 2015, 9, 754-760.

138. Awais, M.; Tariq, M.; Ali, Q.; Khan, A.; Ali, A.; Nasir, I.A.; Husnain, T. Isolation, characterization and association among Phosphate Solubilizing bacteria from sugarcane rhizosphere. Cytol. Genet. 2019, 53, 86-95, doi:10.3103/S0095452719010031.

139. Crespo, J.M.; Boiardi, J.L.; Luna, M.F. Mineral phosphate solubilization activity of Gluconacetobacter diazotrophicus under P-limitation and plant root environment. Agric. Sci. 2011, 2, 16-22.

140. Saini, R.; Dudeja, S.S.; Giri, R.; Kumar, V. Isolation, characterization, and evaluation of bacterial root and nodule endophytes from chickpea cultivated in Northern India. J. Basic Microbiol. 2015, 55, 74-81.

141. Chhabra, S.; Sharma, P. Non rhizobial endophytic bacteria from Chickpea (Cicer arietinum L.) tissues and their antagonistic traits. J. Appl. Nat. Sci. 2019, 11, 346-351.

142. Maheshwari, R.; Bhutani, N.; Suneja, P. Screening and Characterization of siderophore producing endophytic bacteria from Cicer arietinum and Pisum sativum plants. J. Appl. Biol. Biotechnol. 2019, 7, 714, doi:10.7324/JABB.2019.70502.

143. Walpola, B.C.; Yoon, M. Phosphate solubilizing bacteria: assessment of their effect on growth promotion and phosphorous uptake of mung bean (Vigna radiata [L.] R. Wilczek). Chilean J. Agric. Res. 2013, 73, $275-281$. 
144. Kolekar, S.S.; Desai, P.D.; Pancahal, H.K.; Shah, K.B. Study of phosphate solubilizing microorganisms with biofertilizer potential. Int. J. Pharm. Bio. Sci. 2017, 8, 751-757.

145. Bakhshandeh, E.; Rahimian, H.; Pirdashti, H.; Nematzadeh, G. Evaluation of phosphate-solubilizing bacteria on the growth and grain yield of rice (Oryza sativa L.) cropped in northern Iran. J. Appl. Microbiol. 2015, 119, 1371-1382.

146. Teshome, B.; Wassie, M.; Abatneh, E. Isolation, Screening and Biochemical Characterization of PhosphateSolubilizing Rhizobacteria Associated with Coffea arabica L.; 2017.

147. Muleta, D.; Assefa, F.; Börjesson, E.; Granhall, U. Phosphate-solubilising rhizobacteria associated with Coffea arabica L. in natural coffee forests of southwestern Ethiopia. Journal of the Saudi Society of Agricultural Sciences 2013, 12, 73-84, doi:10.1016/J.JSSAS.2012.07.002.

148. Baliah, N.T.; Pandiarajan, G.; Kumar, B.M. Isolation, identification and characterization of phosphate solubilizing bacteria from different crop soils of Srivilliputtur Taluk, Virudhunagar District, Tamil Nadu. Trop. Ecol. 2016, 57, 465-474.

149. Verma, T.; Pal, P. Isolation and Screening of Rhizobacteria for various plant growth promoting attributes. Journal of Pharmacognosy and Phytochemistry 2020, 9, 1514-1517, doi:http://www.phytojournal.com/archives/2020/vol9issue1/PartZ/9-1-338-256.pdf.

150. Ahmad, M.; Nadeeem, S.M.; Naveed, M.; Zahid, Z.A. Potassium-Solubilizing Bacteria and their application in Agriculture. In Potassium Solubilizing Microorganisms for Sustainable Agriculture; Meena, V., Maurya, B., Verma, J., Meena, R., Eds.; Springer: New Delhi, 2016; pp. 293-313.

151. Proença, D.N.; Schwab, S.; Baldani, J.I.; Morais, P.V. Diversity and Function of Endophytic Microbial Community of Plants with Economical Potential. In Diversity and Benefits of Microorganisms from the Tropics; De Azevedo, J.L., Quecine, M.C., Eds.; Springer: Cham, 2017; pp. 209-243.

152. Bahadur, I.; Maurya, B.; Roy, P.; Kumar, A. Potassium-Solubilizing Bacteria (KSB): A Microbial Tool for K-Solubility, Cycling, and Availability to Plants. In Plant Growth Promoting Rhizobacteria for Agricultural Sustainability; Kumar, A., Meena, V., Eds.; Springer: Singapore, 2019; pp. 257-265.

153. Parmar, P.; Sindhu, S.S. Potassium solubilization by rhizosphere bacteria: influence of nutritional and environmental conditions. J. Microbiol. Res. 2013, 31, 25-31.

154. Bhattacharyya, S.; Bachani, P.; Jain, D.; Patidar, S.K.; Mishra, S. Extraction of potassium from K-feldspar through potassium solubilization in the halophilic Acinetobacter soli (MTCC 5918) isolated from the experimental salt farm. Int. J. Min. Process. 2016, 152, 53-57.

155. Mohammadi, K.; Sohrabi, Y. Bacterial Biofertilizers for Sustainable Crop production: A Review. ARPN J. Agric. Biol. Sci. 2012, 7, 307-316.

156. Kumar, P.; Dubey, R.C. Plant Growth Promoting Rhizobacteria for Biocontrol of Phytopathogens and Yield Enhancement of Phaseolus vulgaris. J. Curr. Pers. Appl. Microbiol. 2012, 1, 6-38.

157. Mohamed, H.M.; El-Homosy, R.F.; Abd-Ellatef, A.H.; Salh, F.M.; Hussein, M.Y. Identification of Yeast Strains Isolated from Agricultural Soils for Releasing Potassium-bearing Minerals. Geomicrobiol. J. 2017, 34, 261-266, doi:10.1080/01490451.2016.1186762.

158. Basak, B.B.; Biswas, D.R. Modification of waste mica for alternative source of potassium: Evaluation of potassium release in soil from waste mica treated with potassium solubilizing bacteria (KSB); Lap Lambert Academic Publishing: India, 2012;

159. Zhang, A.; Zhao, G.; Gao, T.; Wang, W.; Li, J.; Zhang, S.; Zhu, B. Solubilization of insoluble potassium and phosphate by Paenibacillus kribensis CX-7: a soil microorganism with biological control potential. Afr. J. Microbiol. Res. 2013, 7, 41-47. 
160. Verma, P.; Yadav, A.N.; Khannam, K.S.; Panjiar, N.; Kumar, S.; Saxena, A.K.; Suman, A. Assessment of genetic diversity and plant growth promoting attributes of psychrotolerant bacteria allied with wheat (Triticum aestivum) from the Northern hills zone of India. Ann. Microbiol. 2015, doi:10.1007/s13213-0141027-4.

161. Laxita, L.; Shruti, S. Isolation and Characterization of Potassium Solubilizing Microorganisms from South Gujarat Region and their effects on Wheat Plant. Mukt Shabd Journal 2020, 9, 7483-7496.

162. Kumar, A.; Kumar, A.; Devi, S.; Patil, S.; Payal, C.; Negi, S. Isolation, screening and characterization of bacteria from Rhizospheric soils for different plant growth promotion (PGP) activities: an in vitro study. Rec. Res. Sci. Technol. 2012, 4, 1-5.

163. Parmar, K.B.; Mehta, B.P.; Kunt, M.D. Isolation, characterization and identification of potassium solubilizing bacteria from rhizosphere soil of maize (Zea mays). Int. J. Sci. Environ. Technol. 2016, 5, 30303037.

164. Imran, M.; Shahzad, S.M.; Arif, M.S.; Yasmeen, T.; Ali, B.; Tanveer, A. Inoculation of Potassium Solubilizing Bacteria with different Potassium Fertilization Sources mediates Maize Growth and Productivity. Pak. J. Agic. Sci. 2020, 57, 1045-1055.

165. Archana, D.S.; Nandish, M.S.; Savalagi, V.P.; Alagawadi, A.R. Characterization of potassium solubilizing bacteria (KSB) from rhizosphere soil. Bioinfolet. 2013, 10, 248-257.

166. Sangeeth, K.; Bhai, R.S.; Srinivasan, V. Paenibacillus glucanolyticus, a promising potassium solubilizing bacterium isolated from black pepper (Piper nigrum L.) rhizosphere. J. Spices Aromat. Crops 2012, 21, 118124.

167. Han, H.S.; Lee, K.D. Effect of co-inoculation with phosphate and potassium solubilizing bacteria on mineral uptake and growth of pepper and cucumber. Plant Soil Environ. 2006, 52, 130-131.

168. Valverde, A.; Burgos, A.; Fiscella, T.; Rivas, R.; Velazquez, E.; Rodriguez-Barrueco, C.; Cervantes, E.; Chamber, M.; Igual, J.M. Differential effects of coinoculations with Pseudomonas jessenii PS06 (a phosphate-solubilizing bacterium) and Mesorhizobium ciceri C-2/2 strains on the growth and seed yield of chickpea under greenhouse and field conditions. Plant Soil 2006, 287, 43-50.

169. Shravanthi, G.V.; Panchatcharan, P.; Rani, S.A.; Ambikapathy, V. Screening of potassium solubilzing bacteria and their growth promoters. Journal of Pharmacognosy and Phytochemistry 2019, 8, 661-664.

170. Mehta, P.; Walia, A.; Shirkot, C.K. Functional diversity of phosphate solubilizing plant growth promoting rhizobacteria isolated from apple trees in the Trans Himalayan region of Himachal Pradesh, India. Biol. Agric. Hortic. 2015, 31, 265-288, doi:10.1080/01448765.2015.1014420.

171. Chen, Y.H.; Yang, X.Z.; Li, Z.; An, X.H.; Ma, R.P.; Li, Y.P.; Cheng, C.G. Efficiency of potassiumsolubilizing Paenibacillus mucilaginosus for the growth of apple seedling. Journal of Integrative Agriculture 2020, 19, 2458-2469, doi:10.1016/S2095-3119(20)63303-2.

172. Shaaban, E.A.; El-Shamma, I.M.S.; El-Shazly, S.; El-Gazzar, A.; Abdel-Hak, R.E. Efficiency of rockfeldspar combined with silicate dissolving bacteria on yield and fruit quality of valencia orange fruits in reclaimed soils. J. Appl. Sci. Res. 2012, 8, 4504-4510.

173. Setiawati, T.C.; Mutmainnah, L. Solubilization of Potassium containing mineral by microorganisms from sugarcane Rhizosphere. Agri. Sci. Procedia 2016, 9, 108-117.

174. Sattar, A.; Naveed, M.; Ali, M.; Zahir, Z.A.; Nadeem, S.M.; Yaseen, M.; Meena, V.S.; Farooq, M.; Singh, R.; Rahman, M.; et al. Perspectives of potassium solubilizing microbes in sustainable food production system: A review. Appl. Soil Ecol. 2019, 133, 146-159, doi:10.1016/j.apsoil.2018.09.012. 
175. Liu, D.; Lian, B.; Dong, H. Isolation of Paenibacillus sp. and assessment of its potential for enhancing mineral weathering. Geomicrobiol. J. 2012, 29, 413-421.

176. Meena, S.V.; Maurya, B.R.; Meena, S.K.; Mishra, P.K.; Bisht, J.K.; Pattanayak, A. Potassium solubilization: Strategies to mitigate potassium deficiency in agricultural soils. Global J. Biol. Agric. Health Sci. 2018, 7, 13.

177. Sindhu, S.S.; Dua, S.; Verma, M.K.; Khandelwal, A. Growth promotion of legumes by inoculation of rhizosphere bacteria. In Microbes for legume improvement; Kan, M.S., Zaidi, A., Musarrat, J., Eds.; SpringerWien: New York, 2010; pp. 195-235.

178. Meena, V.S.; Maurya, B.R.; Verma, J.P.; Aeron, A.; Kim, K.; Bajpai, V. Potassium solubilizing rhizobacteria (KSR): Isolation, identification, and K-release dynamics from waste mica. Ecol. Eng. 2015, 81, 340-347.

179. Sindhu, S.S.; Parmar, P.; Phour, M.; Sehrawat, A. Potassium-Solubilizing Microorganisms (KSMs) and its Effect on Plant Growth improvement. In Potassium Solubilizing Microorganisms for Sustainable Agriculture; Meena, V., Maurya, B., Verma, J., Meena, R., Eds.; Springer: New Delhi, 2016; pp. 175-185.

180. Teotia, P.; Kumar, V.; Kumar, M.; Shrivastava, N.; Varma, A. Rhizosphere microbes: potassium solubilization and crop productivity-present and future aspects. In Potassium Solubilizing microorganisms for sustainable agriculture; Meena, V., Maurya, B., Verma, J., Meena, R., Eds.; Springer: New Delhi, 2016; pp. 315-325.

181. Goteti, P.K.; Emmanuel, L.A.E.; Desai, S.; Shaik, M.H.A. Prospective zinc solubilising bacteria for enhanced nutrient uptake and growth promotion in maize (Zea mays L.). Int. J. Microbiol. 2013, 2013, 869697, doi:10.1155/2013/869697.

182. Sharifi, P.; Paymozd, M. Effect of zinc, iron and manganese on yield and yield components of green beans. Curr. Opin. Agric. 2016, 5, 15-18.

183. Sindhu, S.S.; Sharma, R.; Sindhu, S.; Phour, M. Plant Nutrient Management Through Inoculation of ZincSolubilizing Bacteria for Sustainable Agriculture. In Biofertilizers for Sustainable Agriculture and Environment; Giri, B., Prasad, R., Wu, Q.S., Varma, A., Eds.; Soil Biology; Springer: Cham, 2019; Vol. 55, pp. 173-201.

184. Bapiri, A.; Asgharzadeh, A.; Mujallali, H.; Khavazi, K.; Pazira, E. Evaluation of zinc solubilization potential by different strains of fluorescent Pseudomonads. J. Appl. Environ. Manage. 2012, 16, $295-298$.

185. Mishra, D.J.; Mishra, U.K.; Shahi, S.K. Role of bio-fertilizer inorganic agriculture: a review. Res. J. Recent. Sci. 2013, 2, 39-41.

186. Shaikh, S.; Saraf, M. Zinc biofortification: Strategy to conquer zinc malnutrition through zinc solubilizing PGPR's. Biomed. J. Sci. Tech. Res. 2017, 1, 224-226, doi:10.26717/BJSTR.2017.01.000158.

187. Zamana, Q.; Aslama, Z.; Yaseenb, M.; Ihsanc, M.Z.; Khaliqa, A.; Fahadd, S.; Barshirb, S.; Ramzanic, P.M.A.; Naeeme, M. Zinc biofortification in rice: leveraging agriculture to moderate hidden hunger in developing countries. Arch. Agron. Soil Sci. 2018, 64, 147-161.

188. Naz, I.; Ahmad, H.; Khokhar, S.N.; Khan, K.; Shah, A.H. Impact of zinc solubilizing bacteria on zinc contents of wheat. Am. Euras. J. Agric. Environ. Sci. 2016, 16, 449-454.

189. Sharma, S.K.; Sharma, M.P.; Ramesh, A.; Joshi, O.P. Characterization of zinc-solubilizing Bacillus isolates and their potential to influence zinc assimilation in soybean seeds. J. Microbiol. Biotechnol. 2012, 22, 352359. 
190. Kamran, S.; Shahid, I.; Baig, D.N.; Rizwan, M.; Malik, K.A.; Mehnaz, S. Contribution of Zinc Solubilizing Bacteria in Growth Promotion and Zinc Content of Wheat. Front. Microbiol. 2017, 8, 2593, doi:10.3389/fmicb.2017.02593.

191. Dinesh, A.; Srinivasan, V.; Hamza, S.; Sarathambal, C.; Anke Gowda, S.J.; Ganeshamurthy, A.N.; Gupta, S.B.; Aparna Nair, V.; Subila, K.P.; Lijina, A.; et al. Isolation and characterization of potential Zn solubilizing bacteria from soil and its effects on soil $\mathrm{Zn}$ release rates, soil available $\mathrm{Zn}$ and plant $\mathrm{Zn}$ content. Geoderma 2018, 321, 173-186, doi:10.1016/j.geoderma.2018.02.013.

192. Khande, R.; Sushil, K.S.; Ramesh, A.; Mahaveer, P.S. Zinc solubilizing Bacillus strains that modulate growth, yield and zinc biofortification of soybean and wheat. Rhizosphere 2017, 4, 126-138, doi:10.1016/j.rhisph.2017.09.002.

193. Sunithakumari, K.; Padma, D.S.N.; Vasandha, S. Zinc solubilizing bacterial isolates from the agricultural fields of Coimbatore, TamilNadu, India. Curr. Sci. 2016, 110, 196-205.

194. Yaghoubi, K.M.; Pirdashti, H.; Rahimian, H.; Nematzadeh, G.; Ghajar, S.M. Potassium solubilising bacteria (KSB) isolated from rice paddy soil: from isolation, identification to K use efficiency. Symbiosis 2017, 76, 23, doi:10.1007/s13199-017-0533-0.

195. Joshi, D.; Negi, G.; Vaid, S.; Sharma, A. Enhancement of Wheat Growth and Zn Content in Grains by Zinc Solubilizing Bacteria. Int. J. Agric. Environ. Biotechnol. 2013, 6, 363-370, doi:10.5958/j.2230732X.6.3.004.

196. Ramesh, A.; Sharma, S.K.; Sharma, M.P.; Yadav, N.; Joshi, O.P. Inoculation of zinc solubilizing Bacillus aryabhattai strains for improved growth, mobilization and biofortification of zinc in soybean and wheat cultivated in vertisols of central India. Appl. Soil Ecol. 2014, 73, 87-96, doi:10.1016/j.apsoil.2013.08.009.

197. Hussain, A.; Arshad, M.; Zahir, Z.A.; Asghar, M. Prospects of zinc solubilizing bacteria for enhancing growth of maize. Pak. J. Agic. Sci. 2015, 52, 915-922.

198. Abaid-Ullah, M.; Hassan, M.N.; Jamil, M.; Brader, G.; Shah, M.K.N.; Sessitsch, A.; Hafeez, F.Y. Plant growth promoting rhizobacteria: an alternate way to improve yield and quality of wheat (Triticum aestivum). Int. J. Agric. Biol. 2015, 17, 51-60.

199. Perumal, M.D.; Selvi, D.; Balachandar, D. Enhanced Zinc Nutrient and Enzyme Activity of Rice Crop by Zinc Solubilizing Bacteria with Zn sources in Zn Deficient Rice Soil. Madras Agric. J. 2019, 106, 171-177.

200. Suman, A.; Yadav, A.; Verma, P. Endophytic Microbes in Crops: Diversity and Beneficial Impact for Sustainable Agriculture. In Microbial Inoculants in Sustainable Agricultural Productivity; Singh, D.P., Singh, H., Prabha, R., Eds.; Springer: New Delhi, 2016; pp. 117-143.

201. Saha, M.; Sarkar, S.; Sarkar, B.; Sharma, B.K.; Bhattacharjee, S.; Tribedi, P. Microbial siderophores and their potential applications: a review. Environ. Sci. Pollut. Res. 2016, 23, 3984-3999.

202. Rajkumar, M.; Ae, N.; Prasad, M.N.V.; Freitas, H. Potential of siderophore-producing bacteria for improving heavy metal phytoextraction. Trends Biotechnol. 2010, 28, 142-149.

203. Arora, N.K.; Verma, M. Modified microplate method for rapid and efficient estimation of siderophore produced by bacteria. 3 Biotech. 2017, 7, 381, doi:10.1007/s13205-017-1008-y.

204. Mhlongo, M.I.; Piater, L.A.; Madala, N.E.; Labuschagne, N.; Dubery, I.A. The Chemistry of PlantMicrobe Interactions in the Rhizosphere and the Potential for Metabolomics to Reveal Signaling Related to Defense Priming and Induced Systemic Resistance. Front. Plant Sci. 2018, 9, 112, doi:http://doi.org/10.3389/fpls.2018.00112.

205. Tank, N.; Rajendran, N.; Patel, B.; Saraf, M. Evaluation and biochemical characterization of a distinctive pyoverdin from a Pseudomonas isolated from chickpea rhizosphere. Braz. J. Microbiol. 2012, 43, 639-648. 
206. Mitter, B.; Petric, A.; Shin, M.W.; Ghain, P.S.G.; Hauberg-Lotte, L.; Reinhold-Hurek, B.; Nowak, J.; Sessitsch, A. Comparative genome analysis of Burkholderia phytofirmans PsJN reveals a wide spectrum of endophytic lifestyles based on interaction strategies with host plants. Front. Plant Sci. 2013, 4, 120.

207. Olanrewaju, O.S.; Glick, B.R.; Babalola, O.O. Mechanisms of action of plant growth promoting bacteria. World J. Microbiol. Biotechnol. 2017, 33, 197.

208. Sah, S.; Singh; Singh, R. Iron acquisition in maize (Zea mays L.) using Pseudomonas siderophore. 3 Biotech 2017, 7, 121.

209. Vendan, R.T.; Yu, Y.J.; Lee, S.H.H.; Rhee, Y.H. Diversity of endophytic bacteria in ginseng and their potential for plant growth promotion. J. Microbiol. 2010, 48, 559.

210. Ghavami, N.; Alikhani, H.A.; Pourbabei, A.A.; Besharati, H. Effects of two new siderophore-producing rhizobacteria on growth and iron content of maize and canola plants. J. Plant Nutr. 2017, 40, 736-746, doi:10.1080/01904167.2016.1262409.

211. Liaqat, F.; Eltem, R. Identification and characterization of endophytic bacteria isolated from in vitro cultures of peach and pea rootstocks. 3 Biotech 2016, 6, 2-9.

212. Ouma, S.O.; Magiri, E.N.; Maritu, V.N.; Mugweru, J.; Ngamau, C. Evaluation of Nitrogen Fixation ability of Endophytic Bacteria in Kenyan Bananas (Musa Spp.) using Biochemical and Molecular Techniques. Int. J. Sci. Technol. 2014, 2, 156-163.

213. Kashyap, A.S.; Pandey, V.K.; Manzar, N.; Kannojia, P.; Singh, U.B.; Sharma, P.K. Role of Plant GrowthPromoting Rhizobacteria for improving Crop Productivity in Sustainable Agriculture. In Plant-microbe interactions in agro-ecological perspectives; Singh, D., Prabha, R., Eds.; Springer: Singapore, 2017; pp. 673693.

214. Rasouli-Sadaghiani, M.; Malakouti, M.J.; Khavazi, K.; Miransari, M. Siderophore efficacy of fluorescent pseudomonades affecting labeled iron (59Fe) uptake by wheat (Triticum aestivum L.) genotypes differing in Fe efficiency. In Use of microbes for the alleviation of soil stresses; Miransari, M., Ed.; Springer: New York, 2014; pp. 121-132.

215. Novo, L.A.; Castro, P.M.; Alvarenga, P.; da Silva, E.F. Plant growth-promoting rhizobacteria-assisted phytoremediation of mine soils. In Bio-geotechnologies for mine site rehabilitation; Prasad, M.N.V., de Campos, F.P.J., Maiti, S.K., Eds.; Elsevier Inc.: Amsterdam, 2018.

216. Aloo, B.N.; Mbega, E.R.; Makumba, B.A. Rhizobacteria-Based Technology for Sustainable Cropping of Potato (Solanum tuberosum L.). Potato Res. 2019, 1-21, doi:10.1007/s11540-019-09432-1.

217. Bharti, N.; Sharma, S.K.; Saini, S.; Verma, A.; Nimonkar, V.; Prakash, O. Microbial Plant Probiotics: Problems in Application and Formulation. In Probiotics and Plant Health; Kumar, V., Kumar, M., Sharma, S., Prasad, R., Eds.; Springer: Singapore, 2017; pp. 317-335.

218. FAO Fast facts: The State of the World's Land and Water Resources Available online: www. fao.org/nr/solaw/solaw-home/en (accessed on Oct 25, 2019).

219. BCC Research Global Market for Biopesticides; Market Research Reports; Wellesley, MA, 2014; pp. 1-137;.

220. Grand View Research Biofertilizers market analysis by product (nitrogen fixing, phosphate solubilizing), by application (seed treatment, soil treatment) and segment forecasts to 20222015.

221. Owen, D.; Williams, A.P.; Griffith, G.W.; Withers, P.J.A. Use of commercial bioinoculants to increase agricultural production through improved phosphorus acquisition. Appl. Soil Ecol. 2015, 86, 41-54.

222. Transparency Market Research Biofertilizers market (Nitrogen fixing, phosphate solubilizing and others) for seed treatment and soil treatment applications - Global industry analysis, size, share, growth, trends and forecast, 2013-2019 2017. 
223. Khatibi, R. Using sulfur oxidizing bacteria and P solubilizing for enhancing phosphorous availability to Raphanus sativus. Afr. J. Plant Sci. 2011, 5, 430-435.

224. Celador-Lera, L.; Jiménez-Gómez, A.; Menéndez, E.; Rivas, R. Biofertilizers Based on Bacterial Endophytes Isolated from Cereals: Potential Solution to Enhance These Crops. In Stress Management and Agricultural Sustainability; Meena, V.S., Ed.; Role of Rhizospheric Microbes in Soil; Springer: Singapore, 2018; Vol. 1, pp. 175-203.

225. Adeleke, R.A.; Raimi, A.R.; Roopnarain, A.; Mokubedi, S.M. Status and Prospects of Bacterial Inoculants for Sustainable Management of Agroecosystems. In Biofertilizers for Sustainable Agriculture and Environment; Giri, B., Prasad, R., Wu, Q.S., Varma, A., Eds.; Springer International Publishing: Cham, 2019; pp. 137-172.

226. Odoh, C.K.; Eze, C.N.; Akpi, U.K.; Unah, V.U. Plant growth promoting rhizobacteria (PGPR): A novel Agent for sustainable Food production. Am. J. Agric. Biol. Sci. 2019, 14, 35-54, doi:10.3844/ajabssp.2019.35.54.

227. Mishra, J.; Arora, N.K. Bioformulations for plant growth promotion and combating phytopathogens: a sustainable approach. In Bioformulations: for sustainable agriculture; Arora, N.K., Mehnaz, S., Balestrini, R., Eds.; Springer: New Delhi, 2016; pp. 3-33.

228. Mustafa, S.; Kabir, S.; Shabbir, U.; Batool, R.S. Plant growth promoting rhizobacteria in sustainable agriculture: from theoretical to pragmatic approach. Symbiosis 2019, 78, 115-123, doi:10.1007/s13199-01900602-w.

229. Sekar, J.; Raj, R.; Prabavathy, V.R. Microbial Consortial Products for Sustainable Agriculture: Commercialization and Regulatory Issues in India. In Agriculturally Important Microorganisms: Commercialization and Regulatory Requirements in Asia; Singh, H.B., Sarma, B.K., Keswani, C., Eds.; Springer Singapore: Singapore, 2016; pp. 107-132.

230. Martínez-Romero, E. Coevolution in Rhizobium-legume symbiosis? DNA cell Biol. 2009, 28, 361-370.

231. Tairo, E.V.; Ndakidemi, P.A. Micronutrients uptake in soybean (Glycine max L.) as affected by Bradyrhizobium japonicum inoculation and phosphorus (p) supplements. World J. Soil Crop Sci. Res. 2014, $1,1-9$.

232. Raimi, A. Quality assessment of Commercial Biofertilisers and the awareness of smallholder farmers in Gauteng province, South Africa. Thesis, University of South Africa, 2018.

233. Rodrigues, E.P.; Rodrigues, L.S.; de Oliveira, A.L.M.; Baldani, V.L.D.; Dos Santos, T.K.R.; Urquiaga, S.; Reis, V.M. Azospirillum amazonense inoculation: effects on growth, yield and N2 fixation of rice (Oryza sativa L.). Plant Soil 2008, 302, 249-261.

234. Grady, E.N.; MacDonald, J.; Liu, L.; Richman, A.; Yuan, Z.C. Current knowledge and perspectives of Paenibacillus: a review. Microbial Cell Fact. 2016, 15, 203.

235. Investing News Network What is potash? From types of potash to potash stocks Available online: https://investingnews.com/daily/resource-investing/agriculture-investing/2013-top-pot ash-p (accessed on Nov 16, 2019).

236. Markets and Markets Global Biofertilizer Markets by types, application and geography-Trends and Forecast 2014.

237. Market Data Forecast Microbial Soil Inoculants Market By Type (Plant Growth Promoting Microorganisms (PGPMs), Bio-control Agents, and Plant-resistance Stimulants), By Crop Type (Cereals \& Grains, Oilseeds \& Pulses, Fruits \& Vegetables, and Other Crops), by Source (Bacterial, Fungal, and Others), by Region - Global Industry Analysis, Size, Share, Growth, Trends, and Forecasts (2018-2023) 
Available online: http://www.marketdataforecast.com/market-reports/microbial-soil-inoculantsmarket-5373/ (accessed on Nov 15, 2019).

238. Bashan, Y. Inoculants of plant growth-promoting bacteria for use in agriculture. Biotechnol Adv. 1998, 16, 726-770.

239. PRWEB Europe bio fertilizer market is expected to reach $\$ 4,582.2$ million in 2017 new report by MicroMarket Monitor Available online: http://www.micromarketmonitor.com/market/europe-biofertilizer-4637178345.html.

240. Micro Market Monitor North America biofertilizer market by application (cereals \& grains, fruits \& vegetables, pulses \& oilseeds), by type (nitrogen fixing biofertilizers, phosphate solubilizing biofertilizers, potash mobilizing biofertilizers), by source, by geography -analysis and forecast to 2019 Available online: http://www.micromarketmonitor.com/market/north-america- bio-fertilizer5250154124.html.

241. Agro News Biofertilizers market-global industry analysis, size, share, growth, trends and forecast, 20132019 Available online: http://news.agropages.com/News/NewsDetail11612-e.htm.

242. Weekley, J.; Gabbard, J.; Nowak, J. Micro-level management of agricultural inputs: emerging approaches. Agronomy 2012, 2, 321-357.

243. Yanni, Y.; Zidan, M.; Dazzo, F.; Mehesen, A.; Abdelfattah, F.; Elsadany, A. Enhanced symbiotic performance and productivity of drought stressed common bean after inoculation with tolerant native rhizobia in extensive fields. Agric. Ecosyst. Environ. 2016, 232, 119-128.

244. Koskey, G.; Mburu, S.W.; Njeru, E.M.; Kimiti, J.M.; Ombori, O.; Maingi, J.M. Potential of Native Rhizobia in Enhancing Nitrogen Fixation and Yields of Climbing Beans (Phaseolus vulgaris L.) in Contrasting Environments of Eastern Kenya. Front. Plant Sci. 2017, 8, 443, doi:10.3389/fpls.2017.00443.

245. Manasa, K.; Reddy, R.S.; Triveni, S.; Kumar, B.K.; Priya, N.G. Characterization of Rhizobium isolates and their potential PGPR characteristics of different rhizosphere soils of Telangana region, India. Int. J. Curr. Microbiol. Appl. Sci. 2017, 6, 2808-2813.

246. Muleta, D.; Ryder, M.H.; Denton, M.D. The potential for rhizobial inoculation to increase soybean grain yields on acid soils in Ethiopia. Soil Sci. Plant Nutr. 2017, 63, 1-11.

247. Berninger, T.; González, L.O.; Bejarano, A.; Preininger, C.; Sessitsch, A. Maintenance and assessment of cell viability in formulation of non-sporulating bacterial inoculants. Microb. Biotechnol. 2018, 11, 277-301, doi:10.1111/1751-7915.12880.

248. European Parliament and Council of the European Union Proposal for a Regulation of the European Parliament and of the Council laying down rules on the making available on the market of CE marked fertilising products and amending Regulations (EC) No 1069/2009 and (EC) No 1107/2009; 2016;

249. Qiu, Z.; Egidi, E.; Liu, H.; Kaur, S.; Singh, B.K. New frontiers in agriculture productivity: Optimised microbial inoculants and in situ microbiome engineering. Biotechnol. Adv. 2019, 37, 107371, doi:10.1016/j.biotechadv.2019.03.010.

250. Nakkreen, S.; Fernando, D.W.G.; Siddiqui, Z.A. Plant growth promoting rhizobacteria formulations and its scope in commercialization for the management of pests and diseases. In Biocontrol and Biofertilization; Siddiqui, Z.A., Ed.; Springer: Dordrecht, 2005; pp. 257-296.

251. Gopalakrishnan, S.; Sathya, A.; Vijayabharathi, R.; Srinivas, V. Formulations of Plant Growth-Promoting Microbes for Field Applications. In Microbial Inoculants in Sustainable Agricultural Productivity; Singh, D., Singh, H., Prabha, R., Eds.; Springer: New Delhi, 2016; pp. 239-251. 
252. Ijaz, M.; Ali, Q.; Ashraf, S.; Kamran, M.; Rehman, A. Development of Future Bioformulations for Sustainable Agriculture. In Microbiome in Plant Health and Disease: Challenges and Opportunities; Kumar, V., Prasad, R., Kumar, M., Choudhary, D.K., Eds.; Springer Singapore: Singapore, 2019; pp. 421-446.

253. Gupta, G.; Parihar, S.S.; Ahirwar, N.K.; Sneni, S.K.; Singh, V. Plant growth promoting Rhizobacteria (PGPR): Current and future prospects for development of sustainable agriculture. J. Microbiol. Biochem. 2015, 7, 96-102.

254. Vassilev, N.; Vassilev, M.; Lopez, A.; Martos, V.; Reyes, A.; Maksimovic, I.; EichlerLöbermann, B.; Malusá, E. Unexploited potential of some biotechnological techniques for biofertilizer production and formulation. Appl. Microb. Biotechnol. 2015, 99, 4983-4996, doi:10.1007/s00253-015-6656-4.

255. Khan, W.U.; Ahmad, S.R.; Yasin, N.A.; Ali, A.; Ahmad, A.; Akram, W. Application of Bacillus megaterium MCR-8 improved phytoextraction and stress alleviation of nickel in Vinca rosea. Int. J. Phytoremediation 2017, 19, 813-824, doi:10.1080/15226514.2017.1290580.

256. Sahai, P.; Kumar, V. Carriers and Their Role in Plant Agrosystem. In Probiotics and Plant Health; Kumar, V., Kumar, M., Sharma, S., Prasad, R., Eds.; Springer Singapore: Singapore, 2017; pp. 291-315 ISBN 978981-10-3473-2.

257. Mueller, U.G.; Juenger, T.; Kardish, M.; Carlson, A.; Burns, K.; Smith, C.; De Marais, D. Artificial microbiome-selection to engineer microbiomes that confer salt-tolerance to plants. bioRxiv 2016, 081521.

258. The world of organic agriculture: statistics and emerging trends; Willer, H., Kilchar, L., Eds.; Research Institute of Organic Agriculture (FiBL) and International Federation of Organic Agriculture Movements (IFOAM): Bonn, 2011; 